\title{
Late Quaternary coastal evolution and aeolian sedimentation in the tectonically-active southern Atacama Desert, Chile
}

\author{
David J. Nash $^{\mathrm{a}, \mathrm{b}, *}$, Mark D. Bateman ${ }^{\mathrm{c}}$, Joanna E. Bullard ${ }^{\mathrm{d}}$, Claudio Latorre , $^{\mathrm{f}}$

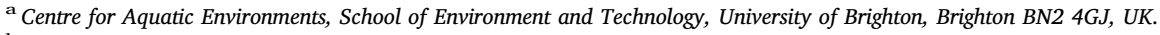 \\ ${ }^{\mathrm{b}}$ School of Geography, Archaeology and Environmental Studies, University of the Witwatersrand, Private Bag 3, Johannesburg 2050, South Africa. \\ ${ }^{\mathrm{c}}$ Department of Geography, University of Sheffield, Winter Street, Sheffield S10 2TN, UK. \\ d Department of Geography, Loughborough University, Loughborough, Leicestershire LE11 3TU, UK. \\ e Centro UC del Desierto de Atacama and Departamento de Ecología, Pontificia Universidad Católica de Chile, Casilla 114-D, Santiago, Chile. \\ ${ }^{\mathrm{f}}$ Institute of Ecology \& Biodiversity (IEB), Las Palmeras 3425, Santiago, Chile
}

\section{A R T I C L E I N F O}

\section{Keywords:}

Aeolianite

OSL dating

Vadose carbonate

Marine terraces

Last glacial-interglacial cycle

\begin{abstract}
A B S T R A C T
Analyses of aeolianites and associated dune, surficial carbonate and marine terrace sediments from north-central Chile $\left(27^{\circ} 54^{\prime} \mathrm{S}\right)$ yield a record of environmental change for the coastal southern Atacama Desert spanning at least the last glacial-interglacial cycle. Optically stimulated luminescence dating indicates phases of aeolian dune construction at around 130, 111-98, 77-69 and 41-28 ka. Thin-section and stable carbon and oxygen isotope analyses suggest a predominantly marine sediment source for the three oldest dune phases. Aeolianites appear to have accumulated mainly from tectonically-uplifted interglacial marine sediments that were deflated during windier and/or stormier intervals. Bedding orientations indicate that sand-transporting winds varied in direction from S-ESE during MIS 5e and WNW-ESE during MIS 5c-5a. Winds from the southeast quadrant are unusual today in this region of the Atacama, suggesting either major shifts in atmospheric circulation or topographic airflow modification. Thin-section evidence indicates that the aeolianites were cemented by two phases of vadose carbonate, tentatively linked to wetter periods around 70 and $45 \mathrm{ka}$. Tectonic uplift in the area has proceeded at an average rate of 305-542 $\mathrm{mm} \mathrm{kyr}^{-1}$. The study illustrates the complexity of understanding onshoreoffshore sediment fluxes in the context of Late Quaternary sea-level fluctuations for an area undergoing rapid tectonic uplift.
\end{abstract}

\section{Introduction}

Evidence for late Quaternary environmental change within the hyperarid Atacama Desert of northern Chile is spatially and temporally limited. Most terrestrial records arise from palaeoecological investigations in the Andean precordillera, are limited to radiocarbon timescales, and thus date back no further than 50 ka (e.g. Betancourt et al., 2000; Latorre et al., 2002, 2003, 2006; Maldonado et al., 2015; Quade et al., 2008; Mujica et al., 2005). These studies indicate increased winter precipitation at $>52,40-33$ and $24-17$ ka south of $25^{\circ} \mathrm{S}$, and increased summer precipitation in two distinct phases from ca.18-14 ka and ca.13.8-9 ka (De Porras et al., 2017). The latter two periods are recognised regionally as the "Central Andean (or Atacama) Pluvial Event" (Placzek et al., 2009; Quade et al., 2008; Gayo et al., 2012; Latorre et al., 2013). Available marine records from offshore of northern Chile span a longer time-period, but are still restricted in number. These show that the Last Interglacial (LIG) and Last Glacial Maximum (LGM) were relatively wet along the coast compared to a dry Holocene, with major wetter and drier periods since 120 ka coinciding broadly with orbital precession maxima and minima, respectively (e.g. Lamy et al., 1998, 2000; Stuut and Lamy, 2004; Kaiser et al., 2008; Contreras et al., 2010).

In the near-coastal zone of north-central Chile, terrestrial palaeoenvironmental investigations are restricted to studies of Holocene swamp forest development (Maldonado and Villagrán, 2002, 2006), late Holocene fog ecosystem evolution (Latorre et al., 2011), rodent middens (Díaz et al., 2012) and Quaternary palaeosols (Pfeiffer et al., 2012). This is due mainly to a lack of sites with suitable organic material for radiocarbon dating. In the absence of biological proxies, analyses of wind-blown sediments offer the greatest potential for understanding past conditions in this zone. Studies of near-coastal transverse dunes have been undertaken in northern Chile (e.g. Araya Vergara, 2001; Paskoff et al., 2003; Castro Avaria et al., 2012) and southern Peru (e.g. Finkel, 1959; Gay, 1962, 1999; Hastenrath, 1967, 1987), with ages of dune initiation (Hesse, 2009a) and periods of

\footnotetext{
* Corresponding author at: School of Environment and Technology, University of Brighton, Brighton BN2 4GJ, UK.

E-mail address: d.j.nash@brighton.ac.uk (D.J. Nash).
} 
A

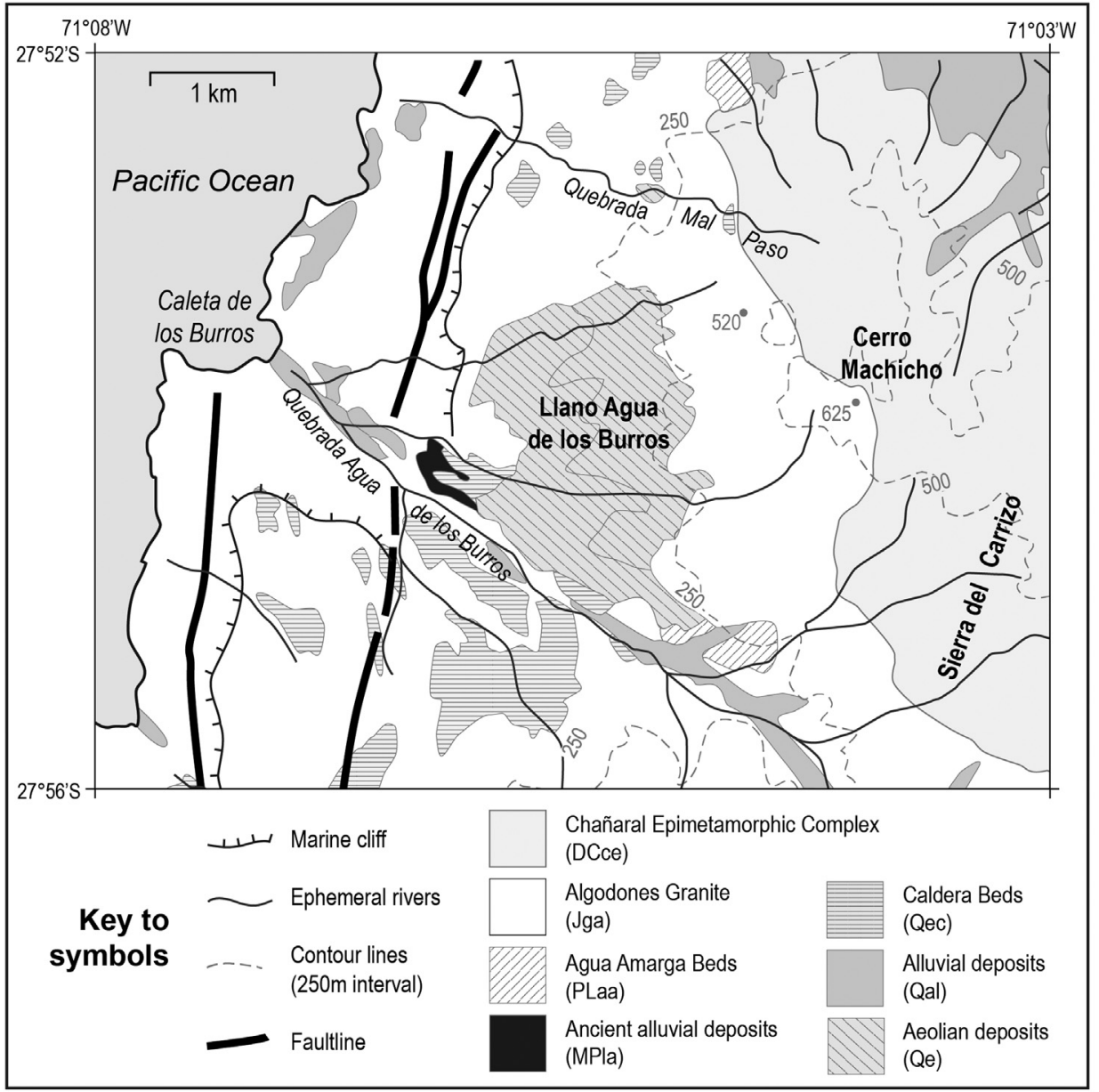

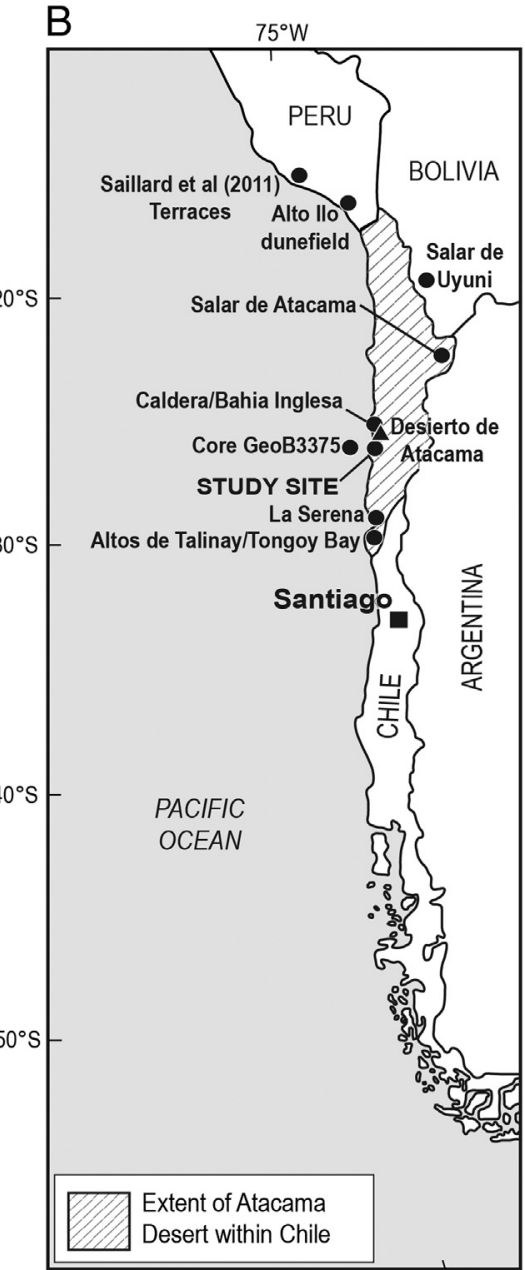

$75^{\circ} \mathrm{W}$

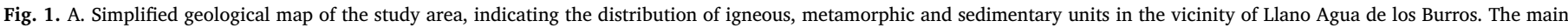
aeolianite outcrop forms the easternmost part of the area of Qe at the centre of the map; B. Location map, including other sites mentioned in the text.

enhanced sediment supply (Hesse, 2009b) in southern Peru estimated from rates of historical sand transport and tectonic contexts. Well-dated studies of near-coastal aeolian deposits are limited to work by Londoño et al. (2012) in the Alto Ilo dunefield, southern Peru (ca. $\left.17^{\circ} 30^{\prime} \mathrm{S}\right)$, and Veit et al. (2015) around La Serena, central Chile (30-33 ${ }^{\circ}$ S). In southern Peru, episodes of aeolian sediment accumulation were identified by optically stimulated luminescence (OSL) at ca.55-45, 38-27, 22-16 and $12 \mathrm{ka}$, generally coincident with periods of enhanced moisture availability in the Peruvian Andes and Altiplano (Londoño et al., 2012). In contrast, aeolian sediment accumulation in central Chile was punctuated by episodes of palaeosol development (PostIR 225 luminescence dated to 135-125, 59-47 and < $14 \mathrm{ka}$ ), implying formation mainly during drier rather than more humid periods (Veit et al., 2015).

This study presents an extensive new palaeoenvironmental dataset derived from near-coastal carbonate aeolianite and associated sediments at Llano Agua de los Burros ( $\left.27^{\circ} 54^{\prime} \mathrm{S}, 071^{\circ} 04^{\prime} \mathrm{W}\right), 70 \mathrm{~km}$ southwest of Copiapó in north-central Chile (Figs. 1 and 2), an area close to the northernmost extent of mediterranean coastal climatic conditions. We combine OSL dating, aeolianite micromorphology, particle size data and stable isotope geochemistry to address two specific research problems: (i) identifying the factors that influenced aeolian sediment accumulation and preservation in the study area; and (ii) determining the impact of rapid regional tectonic uplift upon the nature of the aeolianite sequence. In other parts of the world, carbonate aeolianite has been shown to yield information about offshore sediment production, onshore sediment accumulation, and past climatic conditions, including palaeowind direction and moisture variability (e.g. Fairbridge, 1995; Vacher, 1997; Brooke, 2001; McLaren, 2007; Porat and Botha, 2008; Roberts et al., 2009); we explore similar themes here. The distribution and stacking of aeolianite sequences can also provide information on tectonic regimes (Muhs et al., 2014). In South Africa and most of Australia, coastal aeolianites are located in a tectonicallystable setting, and deposits from numerous glacial-interglacial cycles are stacked vertically (Bateman et al., 2011; Cawthra et al., 2014); those on the Coorong coastal plain in southern Australia, which is slowly uplifting, form barriers across a wide coastal plain (e.g. MurrayWallace et al., 2010). Here, we use our OSL results to independently estimate local uplift rates and assess the influence of rapid uplift upon aeolianite formation.

\section{Regional and site context}

\subsection{Geological and tectonic setting}

Llano Agua de los Burros (LAB) is located $2.5 \mathrm{~km}$ from the Pacific Ocean at the foot of the Sierra del Carrizo coastal range (Fig. 2B), which consists of Devonian-Carboniferous meta-sandstones, slates, phyllites, marbles and metabasites (Blanco et al., 2003). The region is situated above a flat subduction slab (Gutscher et al., 2000) and, as a result, is highly active tectonically. In common with other parts of the coastline of northern Chile and southern Peru, the study area displays uplifted 


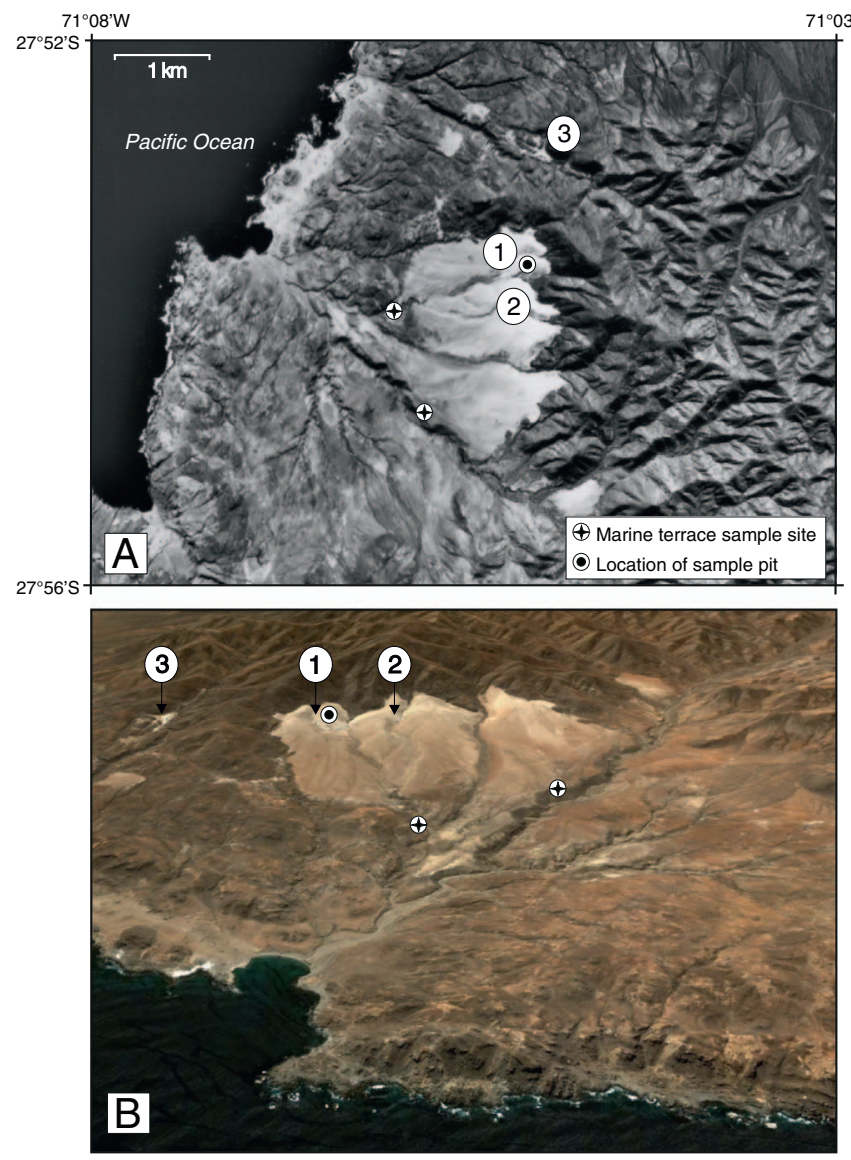

Fig. 2. A. Annotated aerial photograph showing the main sampling localities (numbered 1-3) at Llano Agua de los Burros (image courtesy of Servicio Aerofotogramétrico, Chile); B. Oblique DEM of the study area looking due east towards the Sierra del Carrizo (based upon image from Google Earth, which used data from DigitalGlobe, SIO, NOAA, US Navy, HGA and GEBCO).

marine terraces formed during sea-level highstands (e.g. Saillard et al., 2009, 2011). The sites for this investigation are situated on one such terrace (maximum elevation ca. $130 \mathrm{~m}$ asl), which is cut across TriassicJurassic granite and granodiorite and draped with Quaternary sediments (Blanco et al., 2003) (Fig. 1A). In common with other parts of the coast of north-central Chile, the continental shelf offshore of the study area is relatively narrow and drops steeply towards the Peru-Chile Trench (cf. Rutllant and Montecino, 2002; Contreras-Reyes et al., 2014), with water depths exceeding $100 \mathrm{~m}$ within $1 \mathrm{~km}$ of the present coastline (NOAA Bathymetric Data Viewer; https://maps.ngdc.noaa. gov/viewers/bathymetry/).

Uplifted lithified marine terrace sediments are exposed at maximum heights of ca.130 and $85 \mathrm{~m}$ asl within the Quebrada Agua de los Burros south and west of the study sites. These sediments, and by inference the associated marine terraces, have been suggested from fossil evidence to be Middle Miocene and Upper Miocene-Lower Pliocene in age, respectively (Marchant, 2000; Blanco et al., 2003). Such age estimates contrast markedly with the results of more recent morphostratigraphic, cosmogenic radionuclide and $\mathrm{U}-\mathrm{Th}$ dating of terraces and beach ridges at similar elevations in the nearby Caldera/Bahía-Inglesa $\left(27^{\circ} \mathrm{S}\right)$ and Altos de Talinay/Tongoy bay $\left(31^{\circ} \mathrm{S}\right)$ areas (Marquardt et al., 2004; Quezada et al., 2007; Saillard et al., 2009, 2012; Rodríguez et al., 2013; Fig. 1B). The dating of these terraces suggests ages spanning Marine Isotope Stages (MIS) 11 to 9. Like other areas of emergent continental shelf sediments along the Chilean coast (cf. Le Roux et al., 2005), the marine terraces in the study area are fossil-rich coquinas, suggesting high levels of biological productivity during the Quaternary.

\subsection{Climate and vegetation}

The LAB area is situated within the driest sector of the "Norte Chico", an arid region with a transitional climate between the hyperarid Atacama Desert $\left(18-27^{\circ} \mathrm{S}\right)$ to the north and the semi-arid to mediterranean climate region of central Chile $\left(30-36^{\circ} \mathrm{S}\right)$ to the south (Latorre et al., 2007). Climate along the western slope of the Andes and Atacama is characterised by an austral summer rainfall regime linked to the South American Summer Monsoon (Garreaud, 2009). In the southern Atacama, austral winter rainfall may occur during rare incursions of westerly winds (Vuille and Ammann, 1993; Fuenzalida et al., 2005). Large areas along the coast receive virtually no moisture other than from fog (precipitation levels of $<50 \mathrm{~mm} \mathrm{yr}^{-1}$ ). Hyperaridity in the region is attributed to the blocking influence of the southeast Pacific Subtropical High (PSTH), cold water upwelling, and the rain-shadow effect of the Andes (Cerveny, 1998). Only south of $30^{\circ} \mathrm{S}$ does the amount of winter rainfall increase significantly, with average annual rainfall varying from $<200$ to $>700 \mathrm{~mm} \mathrm{yr}^{-1}$ due to the weakening and northward migration of the PSTH during winter months (Garreaud and Aceituno, 2002).

The wind regime in the southern coastal Atacama is dominated by onshore and along-shore winds blowing from the southwest quadrant (Saavedra et al., 2010). Data from Desierto de Atacama (Fig. 3), the closest meteorological station to the study area (Fig. 1B), indicate that the greatest potential for aeolian sediment transport occurs during the austral spring when the PSTH reaches its maximum strength (FloresAqueveque et al., 2010). Around 70\% of annual sand drift potential is associated with this season, with sediment transport mainly towards the northeast.

Vegetation in the southern coastal Atacama Desert $\left(24-27^{\circ} \mathrm{S}\right)$ is characterised by fog-adapted xeric plant communities in which Crassulacean Acid Metabolism (CAM) species such as the cacti Eulychnia breviflora and Copiapoa spp. are common, as well as other succulents such as Nolana crassiflora (Solanaceae) and Tetragonia maritima (Aizoaceae) (Rundel et al., 1991). Further south (27-30º), dwarf $\mathrm{C}_{3}$ shrubs and grasses become more prevalent. South of $30^{\circ} \mathrm{S}$, mediterranean-type ecosystems are present, comprising a heterogeneous mosaic of dry xerophytic thorn scrub, mesic communities including evergreen sclerophyllous trees in the coastal and Andean foothills, and winter-deciduous trees in the south of the mediterranean climate region (Latorre et al., 2007). Although CAM plants are common, few $\mathrm{C}_{4}$ plants exist along the Chilean coastal zone, notable exceptions being several species of the genus Atriplex (Amaranthaceae).

\section{Materials and methods}

\subsection{Field description and sampling}

Carbonate aeolianites are exposed over an area of at least $2.5 \mathrm{~km}^{2}$ within the main outcrop at Llano Agua de los Burros, and a further $0.1 \mathrm{~km}^{2}$ within the Quebrada Mal Paso ca.1 km to the north (Fig. 2A). The area of subcrop may be of an equivalent size but this is difficult to establish owing to the presence of a windblown sediment cover (Fig. 2B). Aeolianites are exposed continuously over an altitudinal range of $95 \mathrm{~m}$ within the main outcrop, with the lowest exposure at ca. $190 \mathrm{~m}$ asl and the highest at ca. $280 \mathrm{~m}$ asl. The maximum exposed thickness of aeolianite at the Quebrada Mal Paso site is ca.15 m. The base of the cemented sediments is not visible at any of the three sites.

The aeolianite sequences were examined and sampled at three localities where the best vertical and lateral exposures were available (Figs. 2 and 4A, B). Two of these (LAB Site 1 at $27^{\circ} 54^{\prime} 20^{\prime \prime} \mathrm{S}, 071^{\circ} 04^{\prime}$ $50^{\prime \prime} \mathrm{W}$; LAB Site 2 at $27^{\circ} 54^{\prime} 40^{\prime \prime} \mathrm{S}, 071^{\circ} 04^{\prime} 45^{\prime \prime} \mathrm{W}$ ) were located at the northernmost end of the main outcrop, where ephemeral streams rising in the Sierra del Carrizo dissect the aeolianite (Fig. 4C) and create exposures of $500 \mathrm{~m}$ (Site 1; Fig. 4A) and $200 \mathrm{~m}$ (Site 2; Fig. 4B) in length. Samples were also collected from a small exposure in the Quebrada Mal 


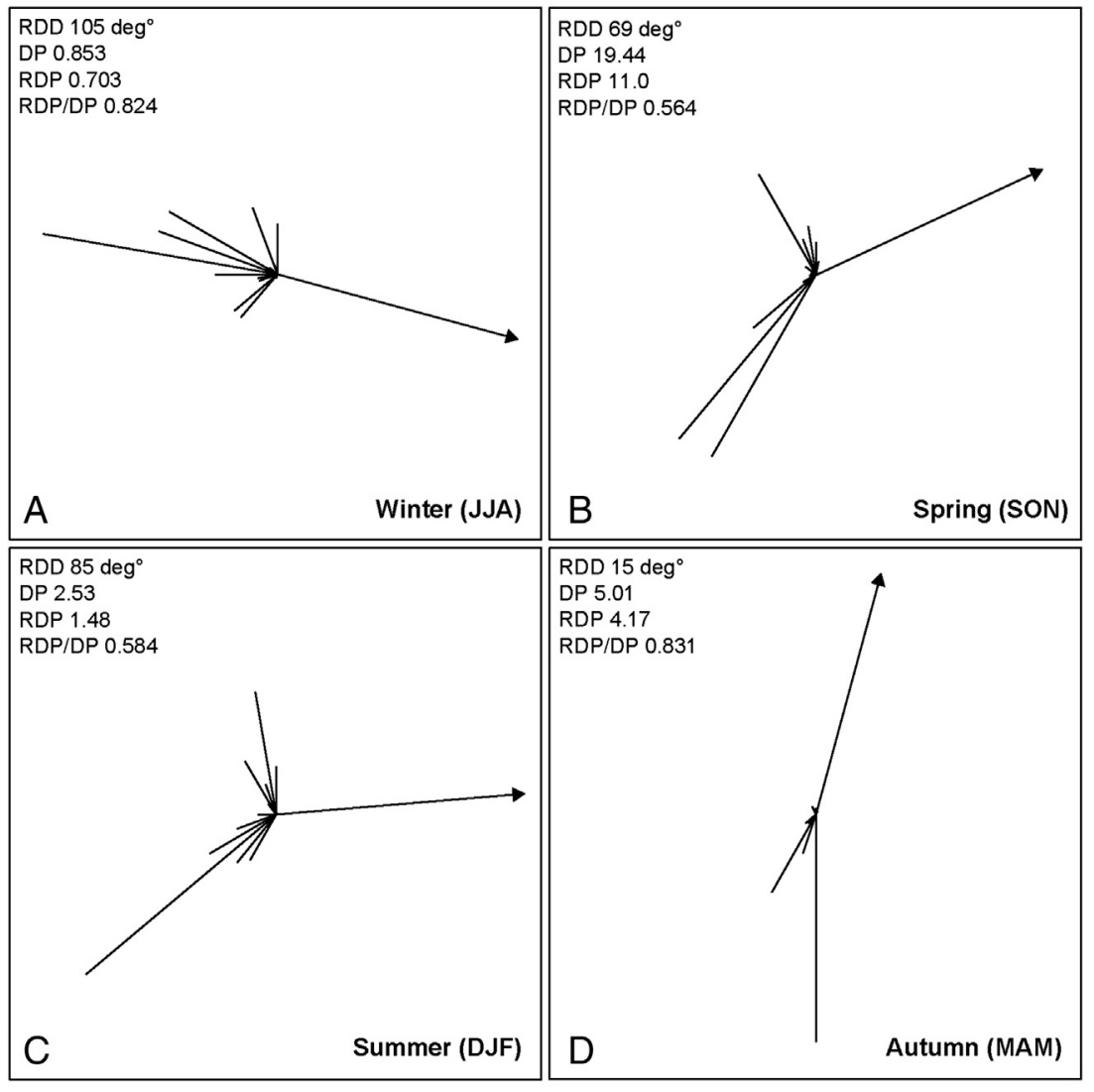

Fig. 3. A.-D. Seasonal sand transport roses for the Desierto de Atacama meteorological station (ca. $80 \mathrm{~km}$ north of the study site; see Fig. 1B), calculated from 2006 to 2015 data using the Fryberger (1979) method modified after Bullard (1997). Calculations assume sand particles of $0.2 \mathrm{~mm}$ diameter to match the modern surface sediment size (see Table 2), and are based on three wind readings per day. The majority of sand-transporting winds occur between September and November, with ca.70\% of drift potential falling within these months. RDD - resultant drift direction; DP - drift potential; $\mathrm{RDP}$ - resultant drift potential.
Paso (LAB Site $3 ; 27^{\circ} 53^{\prime} 30^{\prime \prime}$ S, $071^{\circ} 04^{\prime} 50^{\prime \prime} \mathrm{W}$ ). Sites were described and logged in the field, with cross-cutting relationships and the presence of bounding surfaces used to identify the number of distinct aeolian sedimentary units present (e.g. Fig. 4D). Once these units were defined, the geological dip and strike of each unit was measured at five points randomly distributed across the outcrop. Strike values for each unit were plotted on stereonets and used to estimate the palaeowind direction at the time of sediment deposition (cf. Eastwood et al., 2012). Following Kocurek et al. (1992), only units exhibiting mean dip angles of $\geq 22^{\circ}$ (Table 1 ) were used for the estimation of palaeowind direction, to exclude bedding not associated with former dune slip faces.

At all three sites, oriented aeolianite samples were collected from fresh exposures of each unit for micromorphological and stable $\mathrm{C}$ and $\mathrm{O}$ isotope analyses. Pedogenic and other carbonates were also collected for isotope analysis. These included pedogenic carbonate nodules sampled at $1.3 \mathrm{~m}$ within a $1.8 \mathrm{~m}$ deep pit dug in unconsolidated sand at the highest point (ca.290 m asl) of the windblown sediment overlying the main aeolianite exposure $\left(27^{\circ} 54^{\prime} 20^{\prime \prime} \mathrm{S}, 071^{\circ} 04^{\prime} 40^{\prime \prime} \mathrm{W}\right)$, plus surficial nodular carbonates, rhizoliths, and secondary calcite veins from within the aeolianite around Sites 1 and 2. Representative cubic blocks $(20 \times 20 \times 20 \mathrm{~cm})$ from each aeolianite unit at Sites 1 and 2 were cut for OSL dating, with OSL samples of the unconsolidated sand collected in PVC tubes taken from depths of 0.6 and $1.7 \mathrm{~m}$ within the pit at Site 1 noted above. OSL sampling and laboratory protocols are described below, with supporting data and figures in the Supplementary Online Material [SOM]. Samples of cemented marine terraces exposed within the Quebrada Agua de los Burros were also collected for C and O isotope analyses at $27^{\circ} 54^{\prime} 40^{\prime \prime} \mathrm{S}, 071^{\circ} 05^{\prime} 40^{\prime \prime} \mathrm{W}$, and from a road cutting at $27^{\circ} 55^{\prime} 20^{\prime \prime} \mathrm{S}, 071^{\circ} 05^{\prime} 10^{\prime \prime} \mathrm{W}$ (Fig. 2).

\subsection{Sedimentological and micromorphological analyses}

A sub-sample of each of the aeolianite blocks collected for OSL dating was subjected to particle-size analysis. To determine the particle- size distribution of the host sediments prior to cementation, each subsample was washed repeatedly in $10 \% \mathrm{HCl}$ (by volume) to disaggregate it and remove any $\mathrm{CaCO}_{3}$ cement. High-resolution particle-size analyses of the acid-washed samples were performed using a Beckman-Coulter LS280 laser-sizer in the range $0.375-2000 \mu \mathrm{m}$ with 93 class intervals. Summary statistics (Table 2) were calculated using the geometric method of moments (descriptors follow Folk and Ward, 1957).

A total of 40 aeolianite samples were examined in oriented resinimpregnated thin-section using a petrological microscope to establish the cement stratigraphy and history of diagenesis of each sedimentary unit. Point count data (400 points per microscope slide) were collected for each sample to quantify the proportion of mineral clasts, bioclasts, primary and secondary porosity, and different cement types present (Table 3). Qualitative analysis of each thin-section was used to establish the cement stratigraphy and to identify any post-cementation diagenetic changes.

\subsection{Stable carbon and oxygen isotope analyses}

Aeolianite, nodular carbonates, rhizolith fragments and secondary calcite samples were analysed at Royal Holloway (University of London) using a GV Instruments Multiflow prep system on line to an IsoPrime mass spectrometer. Data were corrected using a calibration based on the known and raw values of two international standards (NBS-19 $\left[\delta^{13} \mathrm{C}+1.95 \%_{\mathrm{VPDB}} ; \delta^{18} \mathrm{O}-2.20 \%{ }_{\mathrm{VPDB}}\right]$ and LSVEC $\left[\delta^{13} \mathrm{C}\right.$ $-46.60 \%$ vPDB; $\left.\left.\delta^{18} \mathrm{O}-26.70 \%{ }_{\mathrm{VPDB}}\right]\right)$, plus Royal Holloway in-house calcite standard RHBNC $\left(\delta^{13} \mathrm{C}+3 \cdot 25 \%{ }^{0}{ }_{\mathrm{VPDB}} ; \delta^{18} \mathrm{O}-10 \cdot 40 \%{ }_{\mathrm{VPDB}}\right)$. The external precision ( $1 \mathrm{sd}$ ) on multiple analyses of the carbonate standards during the sample analysis period was better than $\pm 0.05 \%$ for $\delta^{13} \mathrm{C}$ and $\pm 0.10 \%$ for $\delta^{18} \mathrm{O}$ after scale stretching correction. Samples of plant species from around LAB were also analysed at Royal Holloway to establish their stable carbon isotopic signatures (Table 4). International standards IAEA-CO9 $\left(\delta^{13} \mathrm{C}-47.32 \%{ }_{\mathrm{VPDB}}\right), \quad \mathrm{NBS}-21 \quad\left(\delta^{13} \mathrm{C}\right.$ $\left.-28.10 \%{ }_{\mathrm{VPDB}}\right)$ and USGS-24 $\left(\delta^{13} \mathrm{C}-16.05 \%{ }_{\mathrm{VPDB}}\right)$ plus in-house 

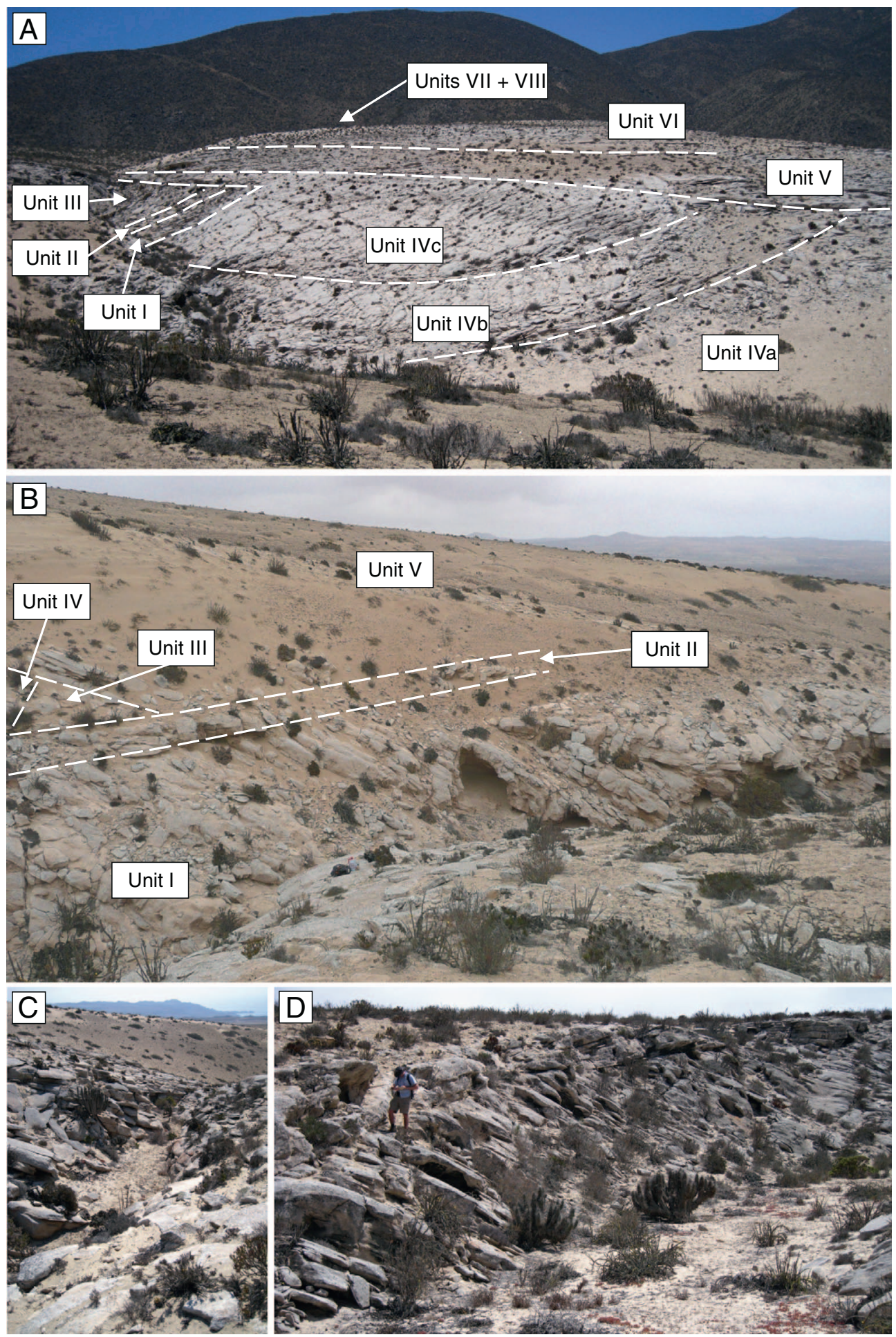

Fig. 4. A. Annotated panoramic view of Site 1 looking due east and showing the stratigraphic relationship between aeolianite sedimentary Units I to VIII. Maximum thickness of aeolianite exposure ca. $95 \mathrm{~m}$; B. View looking SSW across Site 2 showing the stratigraphic relationship between aeolianite sedimentary Units I to V; C. View looking down the quebrada that dissects Site 1 towards the surface of the ca. $130 \mathrm{~m}$ asl marine terrace and the Pacific Ocean; D. Contributor MDB standing at the marked discontinuity between Units I and IVc at Site 1 well-developed foresets are clearly visible in the foreground, with trough cross-bedding in the top right of the image. standards RHBNC and GF $\left(\delta^{13} \mathrm{C}-23.95 \%{ }_{\mathrm{VPDB}}\right)$ were used for calibration.

\subsection{OSL dating}

To avoid sub-sampling potentially light-contaminated sediment within $2 \mathrm{~cm}$ of the block surface, aeolianite block samples were spraypainted black before being cracked open under low intensity red lighting. For the same reason, $2 \mathrm{~cm}$ of end material was removed from each tube sample. The remainder of each sample was sieved and chemically treated to extract $180-250 \mu \mathrm{m}$ diameter quartz grains (Bateman

\section{and Catt, 1996).}

Dose rates were determined from analysis undertaken using inductively coupled plasma mass spectroscopy (ICP-MS) at SGS Laboratories, Canada. Conversions to annual dose rates followed Adamiec and Aitken (1998) for alpha and gamma, and Marsh et al. (2002) for beta, with dose rates attenuated for sediment size and palaeomoisture contents. For the latter, given the hyperaridity of the region with occasional wet phases (see discussion below), a value of $5 \pm 2 \%$ was assumed for all samples. This is similar to Veit et al. (2015) (0-6\%), and palaeomoisture values used for aeolianites in other hyperarid regions (e.g. Preusser et al., 2002; $5 \pm 1 \%$ ). Cosmic dose 
Table 1

Mean dip, strike and palaeowind directional data by aeolianite sedimentary unit (all dip and strike data are plotted on Fig. 6).

\begin{tabular}{|c|c|c|c|c|c|c|c|}
\hline Site & Unit & $\begin{array}{l}\text { Mean dip angle } \\
\left({ }^{\circ}\right)\end{array}$ & $\begin{array}{l}\text { Standard deviation of } \\
\operatorname{dip}\left({ }^{\circ}\right)\end{array}$ & $\begin{array}{l}\text { Mean strike direction } \\
\left({ }^{\circ}\right)\end{array}$ & $\begin{array}{l}\text { Standard deviation of } \\
\text { strike }\left({ }^{\circ}\right)\end{array}$ & $\begin{array}{l}\text { Approximate palaeowind } \\
\text { direction }\left({ }^{\circ}\right)^{\mathrm{a}}\end{array}$ & $\begin{array}{l}\text { Approximate palaeowind } \\
\text { bearing }\end{array}$ \\
\hline \multirow[t]{10}{*}{1} & VIII & 36 & 4.3 & 032 & 5.1 & 122 & SE \\
\hline & VII & 17 & 8.1 & 354 & 14.0 & $\mathrm{n} / \mathrm{a}$ & $\mathrm{n} / \mathrm{a}$ \\
\hline & VI & 34 & 3.6 & 180 & 6.5 & 270 & $\mathrm{~W}$ \\
\hline & $\mathrm{V}$ & 35 & 3.2 & 188 & 10.8 & 278 & W \\
\hline & IVc & 23 & 3.6 & 034 & 6.2 & 124 & SE \\
\hline & IVb & 27 & 2.6 & 029 & 6.6 & 119 & $\mathrm{SE}$ \\
\hline & IVa & 22 & 10.9 & 021 & 10.8 & 111 & ESE \\
\hline & III & 40 & 8.4 & 181 & 10.6 & 271 & $\mathrm{~W}$ \\
\hline & II & 30 & 1.8 & 197 & 11.4 & 287 & WNW \\
\hline & I & 33 & 11.1 & 145 & 9.4 & 235 & SW \\
\hline \multirow[t]{5}{*}{2} & $\mathrm{~V}$ & 19 & 4.3 & 019 & 8.3 & $\mathrm{n} / \mathrm{a}$ & $\mathrm{n} / \mathrm{a}$ \\
\hline & IV & 23 & 5.9 & 102 & 7.7 & 192 & $\mathrm{~S}$ \\
\hline & III & 31 & 0.7 & 063 & 7.8 & 153 & SSE \\
\hline & II & 6 & 1.8 & 112 & 4.3 & $\mathrm{n} / \mathrm{a}$ & $\mathrm{n} / \mathrm{a}$ \\
\hline & I & 25 & 6.0 & 023 & 4.5 & 113 & ESE \\
\hline 3 & I & 35 & 4.1 & 066 & 6.0 & 156 & SSE \\
\hline
\end{tabular}

${ }^{\text {a }}$ Estimated palaeowind direction is only shown for units with mean dip angles $\geq 22^{\circ}$

rates were determined following Prescott and Hutton (1994). We have assumed that the measured radionuclide activities are in equilibrium, given the consistency down profile of $U$ which is potentially mobile, and U:Th ratios (average of 1:2.1) which are not much different to those found commonly for terrestrial sediments, and aeolianites in particular, although lower than average crustal values (1:3.8).

The development of carbonate cement, filling pore spaces, could partially shield quartz grains from background radioactivity, leading to an under-estimation of the true dose-rate (Nathan and Mauz, 2008). To establish an appropriate cementation correction factor, the present-day porosity and carbonate content of the samples were derived from the results of micromorphological analysis (see below). Although the latter indicated multi-phase cementation, as the timing and duration of these phases is unknown, corrections to the external dose received by quartz during its burial were made based on a linear growth. Such an approach has been applied successfully to aeolianites elsewhere (e.g. Andreucci et al., 2010). The effect of this correction was small in terms of dose rate (average change of $0.092 \mathrm{~Gy} \mathrm{kyr}^{-1}$ ), but did make the resultant OSL ages older by an average of $13 \%$ (see Table S1 in the SOM).

For OSL measurements, samples were mounted as a monolayer of grains across a $9.6 \mathrm{~mm}$ diameter disc. Measurements were undertaken with a Ris $\emptyset$ automated luminescence reader. $D_{e}$ values were derived using the single aliquot regeneration (SAR) protocol (Murray and Wintle, 2003). As an IRSL signal was measured in samples, aliquots were stimulated with IR at $50{ }^{\circ} \mathrm{C}$ for 40 s prior to all OSL measurements so that any subsequent OSL signal could be attributed as coming only from quartz. Initial measurements showed the OSL signal to be dim, with around $50 \%$ of signal coming from potentially unstable medium and slow components (Figs. S1 and S2 in the SOM). This is in line with results found by Veit et al. (2015) in Norte Chile. As per Veit et al. (2015), feldspar measurements could have been undertaken but this would have required fading correction and/or quantification of hard-tobleach residual signals. Instead, to mitigate the effects of any unstable signal components, an early background subtraction approach was taken (e.g. Ballarini et al., 2007; Wilson et al., 2008), and the initial $0.5 \mathrm{~s}$ of OSL signal avoided in case this incorporated an unstable ultrafast component. With such an approach, dose recovery tests recovered known doses to within $1.04 \pm 0.11$ of unity (Fig. S3 in the SOM). No aliquots were found to be in saturation, with SAR regeneration points well fitted with a single saturating exponential fit; the naturally acquired dose was interpolated between these points in all cases (Fig. S4 in the SOM). A dose recovery preheat plateau test applied to sample Shfd09043 resulted in the selection of a preheat temperature of $160^{\circ} \mathrm{C}$ for 10 s for all samples (Fig. S5 in the SOM). A minimum of $24 \mathrm{D}_{\mathrm{e}}$ replicates of each sample were measured (Fig. S6 in the SOM).

For five of the eleven samples, the measured $D_{e}$ distributions were unimodal with reasonably low overdispersion (OD; $<25 \%$ ). Whilst at the multi-grained aliquot level and with the number of replicates measured, $\mathrm{D}_{\mathrm{e}}$ heterogeneity may still be masked (Rodnight, 2008), these samples were assumed to have been well bleached on deposition. Final $D_{e}$ values for age calculation for such samples were based on an average $\mathrm{D}_{\mathrm{e}}$ value (Table 5). Six samples displayed multimodal/skewed

Table 2

Summary of particle size data $(\mu \mathrm{m})$ and sedimentological characteristics by unit for Sites 1 and 2 (samples are aeolianite unless otherwise specified).

\begin{tabular}{|c|c|c|c|c|c|c|c|}
\hline Site & Unit & Mean & Median (d50) & Mode & Standard deviation $(\sigma)$ & Skewness (Sk) & Description \\
\hline \multirow[t]{8}{*}{1} & Unconsolidated sand ( $0.8 \mathrm{~m}$ depth) & 214 & 226 & 223 & 1.72 & -5.29 & Unimodal, fine sand, well sorted, symmetrical \\
\hline & Unconsolidated sand (1.7 m depth) & 197 & 224 & 223 & 2.11 & -4.20 & Unimodal, fine sand, moderately well-sorted, fine skewed \\
\hline & VII & 316 & 320 & 269 & 1.82 & -1.99 & Bimodal, medium sand, moderately sorted, symmetrical \\
\hline & $\mathrm{V}$ & 263 & 274 & 269 & 1.59 & -4.73 & Unimodal, medium sand, well-sorted, symmetrical \\
\hline & $\mathrm{IVb}$ & 287 & 302 & 324 & 1.61 & -4.80 & Unimodal, medium sand, well-sorted, fine skewed \\
\hline & III (top) & 280 & 293 & 296 & 1.62 & -4.28 & $\begin{array}{l}\text { Unimodal, medium sand, moderately well-sorted, } \\
\text { symmetrical }\end{array}$ \\
\hline & III (bottom) & 286 & 288 & 296 & 1.36 & -0.13 & Unimodal, medium sand, well sorted, symmetrical \\
\hline & I & 300 & 311 & 324 & 1.59 & -4.64 & $\begin{array}{l}\text { Unimodal, medium sand, moderately well-sorted, } \\
\text { symmetrical }\end{array}$ \\
\hline \multirow[t]{3}{*}{2} & $\mathrm{~V}$ & 328 & 338 & 356 & 1.66 & -3.34 & $\begin{array}{l}\text { Unimodal, medium sand, moderately well-sorted, } \\
\text { symmetrical }\end{array}$ \\
\hline & IV & 291 & 295 & 296 & 1.34 & -0.30 & Unimodal, medium sand, well sorted, symmetrical \\
\hline & I & 379 & 416 & 471 & 1.64 & -4.20 & $\begin{array}{l}\text { Unimodal, medium sand, moderately well sorted, fine } \\
\text { skewed }\end{array}$ \\
\hline
\end{tabular}


Table 3

Mean percentage clasts, porosity and cement types by aeolian sedimentary unit (based on 400 point-counts per thin-section).

\begin{tabular}{|c|c|c|c|c|c|c|c|c|c|c|c|c|}
\hline \multicolumn{3}{|c|}{ Site details } & \multicolumn{2}{|c|}{ Clasts (\%) } & \multicolumn{2}{|c|}{ Porosity (\%) } & \multicolumn{6}{|c|}{ Cement (\%) } \\
\hline Site & Unit & $\begin{array}{l}\text { No. of } \\
\text { samples }\end{array}$ & $\begin{array}{l}\text { Mineral } \\
\text { clasts }\end{array}$ & Bio-clasts & Primary & Secondary & $\begin{array}{l}\text { Grain- } \\
\text { coating } \\
\text { micrite }\end{array}$ & $\begin{array}{l}\text { Grain-coating } \\
\text { micro-sparite }\end{array}$ & $\begin{array}{l}\text { Micrite } \\
\text { meniscus } \\
\text { cement }\end{array}$ & $\begin{array}{l}\text { Micro-sparite } \\
\text { meniscus cement }\end{array}$ & $\begin{array}{l}\text { Pore filling/ } \\
\text { lining micrite }\end{array}$ & $\begin{array}{l}\text { Pore filling/ } \\
\text { lining micro- } \\
\text { sparite }\end{array}$ \\
\hline \multirow[t]{11}{*}{1} & VIII & 1 & 19.0 & 46.8 & 10.8 & 0.5 & 3.5 & 4.5 & 1.8 & 3.3 & 7.5 & 2.5 \\
\hline & VII & 1 & 14.0 & 44.3 & 12.8 & 0.0 & 5.5 & 3.0 & 0.5 & 4.0 & 10.8 & 5.3 \\
\hline & VI & 2 & 16.9 & 38.1 & 23.1 & 0.3 & 6.0 & 5.3 & 1.3 & 3.5 & 2.9 & 2.8 \\
\hline & $\mathrm{V}$ & 3 & 22.0 & 35.6 & 11.8 & 0.2 & 5.2 & 7.8 & 1.4 & 2.8 & 7.0 & 6.2 \\
\hline & IVc & 3 & 18.7 & 35.0 & 19.0 & 0.3 & 5.3 & 5.7 & 1.7 & 2.4 & 6.1 & 5.9 \\
\hline & $\mathrm{IVb}$ & 4 & 14.0 & 36.4 & 18.3 & 0.3 & 6.0 & 6.4 & 0.7 & 3.3 & 6.9 & 7.8 \\
\hline & IVa & 2 & 23.9 & 30.1 & 18.9 & 0.3 & 3.9 & 4.9 & 1.5 & 4.4 & 5.8 & 6.5 \\
\hline & III & 7 & 18.6 & 34.3 & 25.5 & 0.7 & 7.1 & 3.3 & 3.1 & 2.5 & 2.0 & 2.9 \\
\hline & II & 1 & 17.0 & 27.3 & 30.3 & 0.5 & 11.8 & 6.8 & 2.0 & 3.5 & 0.5 & 0.5 \\
\hline & I & 4 & 24.7 & 29.3 & 29.0 & 0.6 & 7.9 & 3.4 & 2.0 & 1.6 & 0.4 & 1.0 \\
\hline & Mean & $n=28$ & 18.9 & 35.7 & 19.9 & 0.4 & 6.2 & 5.1 & 1.6 & 3.1 & 5.0 & 4.1 \\
\hline \multirow[t]{6}{*}{2} & $\mathrm{~V}$ & 2 & 15.3 & 41.1 & 19.4 & 0.0 & 6.3 & 5.5 & 1.1 & 1.6 & 5.4 & 4.4 \\
\hline & IV & 2 & 20.0 & 31.5 & 19.1 & 0.4 & 6.0 & 4.6 & 0.5 & 1.0 & 11.3 & 5.6 \\
\hline & III & 1 & 9.5 & 44.8 & 2.0 & 0.0 & 2.5 & 2.0 & 0.0 & 1.5 & 22.8 & 15.0 \\
\hline & II & 2 & 12.8 & 41.3 & 24.5 & 0.0 & 6.8 & 3.6 & 1.4 & 2.4 & 3.9 & 3.5 \\
\hline & I & 2 & 10.6 & 54.3 & 19.0 & 0.0 & 4.8 & 3.8 & 1.1 & 1.1 & 3.4 & 2.0 \\
\hline & Mean & $n=9$ & 15.9 & 41.3 & 16.2 & 0.2 & 5.3 & 4.5 & 1.1 & 2.4 & 8.0 & 5.1 \\
\hline 3 & I & 3 & 8.8 & 43.2 & 20.3 & 0.0 & 3.3 & 5.8 & 0.8 & 2.8 & 7.0 & 8.2 \\
\hline
\end{tabular}

Table 4

Stable carbon isotope results for selected plant species around the Llano Agua de los Burros sample sites.

\begin{tabular}{ll}
\hline Species & $\delta^{13} \mathrm{C} \%{ }_{\mathrm{VPDB}}$ \\
\hline Nolana glauca & -25.25 \\
Ephedra cf. multiflora & -27.40 \\
Oxalis gigantea & -24.31 \\
Chuquiraga ulicina & -26.44 \\
Chuquiraga ulicina & -26.74 \\
Cynanchum deserticola & -27.17 \\
Cynanchum deserticola & -27.45 \\
\hline
\end{tabular}

$D_{e}$ distributions. As the samples were from well-bedded sediments it is unlikely that this is due to post-depositional disturbance (Bateman et al., 2007). It could instead be caused by (i) micro-dosimetry heterogeneity within the dose rate (Chauhan and Singhvi, 2011), which is relatively low at these sites, (ii) the poor luminescence characteristics of the quartz in these samples, or (iii) poor bleaching. Given all samples are thought to have come from the same source and had the same potential mixing of sediments prior to deposition, it is unclear why only some samples would appear multimodal/skewed if the poor luminescence characteristics were the dominant cause of this. To mitigate these effects, component $D_{e}$ values were extracted by the minimum age model, using a sigma b value of 0.1 (MAM; see Galbraith et al., 1999; Table 5). This minimum $D_{e}$ is assumed to contain the most well bleached grains. As can be seen from Table 5, resultant ages from this approach provide a stratigraphically coherent chronology.

\section{Results}

\subsection{Description of sedimentary sequence}

Fig. 5 shows composite logs of sites 1 and 2, their relative elevations and stratigraphic relationships. Outcrops at all three sites are wellconsolidated, forming vertical cliffs in places and maintaining slope angles in excess of $45^{\circ}$. Some beds are more friable, and have weathered to form alveoli and tafoni. Fresh exposures of aeolianite exhibit a white to light grey (10YR $8 / 1$ to $10 \mathrm{YR} 7 / 1$ ) to very pale brown (10YR $7 / 3$ ) colour. The host sediments are predominantly bioclasts (mainly shell fragments) with minor quartz, feldspar, hornblende, pyroxene, biotite, heavy minerals and lithic fragments. Blanco et al. (2003) also noted the presence of occasional intact gastropods including the land snails Bostryx (Lissoacme) cf. affinis and Bostryx (Lissoacme) cf. pruinosus.

The aeolianite exposures at all three sites are dominated by crossstrata consisting of grainflow and grainfall foresets (Fig. 4D). Largescale (3-4 m) trough cross-bedding structures are also present throughout the exposure. Whilst significant bounding surfaces were observed between units, recent work has shown that such surfaces within dunes may not have a temporal significance (Leighton et al., 2013); no evidence for palaeosols indicating significant palaeosurfaces was seen. It is not possible to determine the exact dune type within which the aeolianite host sediments were deposited. However, on the basis of (i) the topographic position of the aeolianite outcrop fringing the footslopes of the Sierra del Carrizo, and (ii) the nature of most contemporary dune forms in the near-coastal Atacama (see Araya Vergara, 2001; Paskoff et al., 2003), a transverse, climbing or possibly echo dune form is most likely.

The aeolianite outcrop at LAB Site 3 is relatively simple, consisting of a sequence of carbonate cemented grainfall/grainflow foresets with a mean dip of $35^{\circ}$ towards the NNW (Table 1; Fig. 6E). Following Eastwood et al. (2012), and noting the caveats therein concerning the relationship between wind incidence angles and the formation of crossstrata, a SSE sand-transporting palaeowind can be inferred. This may reflect the regional wind direction at the time of sediment deposition; however, the impact of the local topography upon wind fields cannot be overlooked.

The exposures within the main outcrop reveal a more complex depositional history. Based on cross-cutting relationships and variations in the dip and strike of cross-strata (Fig. 6A-C; Table 1), eight distinct aeolian sedimentary units can be identified at LAB Site 1 (Fig. 4A). One of these (Unit IV) was split into three sub-units to reflect a $13^{\circ}$ shift in the mean direction of strike during the course of deposition (Fig. 6B). Inferred palaeowind directions range from WNW (Unit II) to ESE (Unit IVa). Five sedimentary units were identified at LAB Site 2 (Fig. 4B). Inferred palaeowind directions were less variable, ranging from $S$ (Unit IV) to ESE (Unit I) (Fig. 6D).

In terms of their sedimentary characteristics, most of the aeolianite host sediments comprise unimodal, moderately to well rounded, moderately to well sorted medium sands with a symmetrical particle-size distribution (Table 2). Overall, the sediments at LAB Site 1 are slightly finer (modal range $223-324 \mu \mathrm{m}$ ) than those at LAB Site 2 $(291-379 \mu \mathrm{m})$. The particle-size distribution of the unconsolidated near-surface sediment sample at Site 1 is statistically different from all 
the other Site 1 samples (using Kolmogarov-Smirnov Drrit $_{93 ; 0.01}=0.169$ ) and is finer. Units I, II, III, IVb and V from Site 1 are statistically indistinguishable in terms of their particle-size. Unit VII is unusual, being bimodal and exhibiting a broader distribution; it is statistically different to Units III, IVb and V but has some similarities to I and II. At Site 2, the units are all statistically different from one another, and Units I and V are also different from all those at Site 1. Unit IV at Site 2 is indistinguishable from all those at Site 1 with the exceptions of unit VII (oldest) and the unconsolidated sands.

\subsection{Aeolianite micromorphology}

Aeolianite samples from all three sites are clast-supported, comprising on average $54 \%$ carbonate and other mineral/rock fragments, $21 \%$ pore space and $25 \%$ carbonate cement (Table 3 ). Fig. 7 illustrates the vertical variability in the relative proportion of clasts, cement and pore space within samples from LAB Site 1, sampled along a vertical line transect from Unit I to VIII spanning ca. $65 \mathrm{~m}$ vertically. Results suggest a slight decrease in cement content towards the base of the outcrop. Site 1 also shows a decrease in the proportion of bioclasts towards the base of the outcrop, and a lower overall bioclast content than Site 2.

The majority of samples exhibit a combination of simple graincoating (rim), meniscus and pore-lining or pore-filling cements, suggesting formation in a vadose environment (McLaren, 1993, 2007). No pendant or gravity cements were identified. Microscale stratigraphic relationships suggest that cements in the majority of samples were generated during a single main phase of precipitation, although, as described below, some samples with more abundant pore-filling cement exhibit two main generations of cementation. The original aeolian bedding structures are visible in the majority of samples with little evidence of grain displacement during cementation.

Grain-coating cements (Fig. 8A-C) are the most abundant type (on average $47 \%$ of the cement component), and consist typically of a thin $(<50 \mu \mathrm{m})$ layer of micrite or rhombohedral microsparite overlain by scalenohedral 'dog tooth' spar or microspar. Gently concave meniscus cements account for on average $18 \%$ of the cement component, are invariably found in association with grain-coating cements (Fig. 8D, E), but are never the dominant cement type. Individual crystals within meniscus cements have either a bladed or blunt-ended form (cf. McLaren, 1993), and are similar in size to those found in grain-coating cements.

Pore-lining and pore-filling cements are present in more variable proportions, accounting for ca.35\% of the cement component. Porefilling cements range in scale from patches of individual occluded pores, often adjacent to pores devoid of any filling cement, to areas of dense cementation. In samples with only patches of occluded pores, pore-filling cements appear to have developed towards the end of the precipitation of the first generation of grain-coating and meniscus cements. In contrast, pore-filling cements in densely cemented samples clearly postdate the precipitation of first generation cements (Fig. 8F) and indicate two distinct phases of calcite precipitation, with little or no dissolution between cement generations. This is most evident in Units $\mathrm{V}$ and VII at Site 1, Unit I at Site 3 and, most significantly, Units III and IV at Site 2 (Table 3).

The relationship between the host sediment clasts and cements provides an indication of potential sources of calcite cement. In the majority of samples, the contact between carbonate clasts and cements is fretted, suggesting partial dissolution (particularly of aragonite shell material) by percolating meteoric water during subaerial diagenesis. This dissolved carbonate is the most likely source for the development of first generation grain-coating and meniscus cements within samples (cf. Dravis, 1996). The low levels of secondary porosity within samples, however, indicate that dissolution was not extensive, making it unlikely that the calcite for the second generation of pore-filling cements was supplied internally. Dissolved calcium carbonate within percolating 


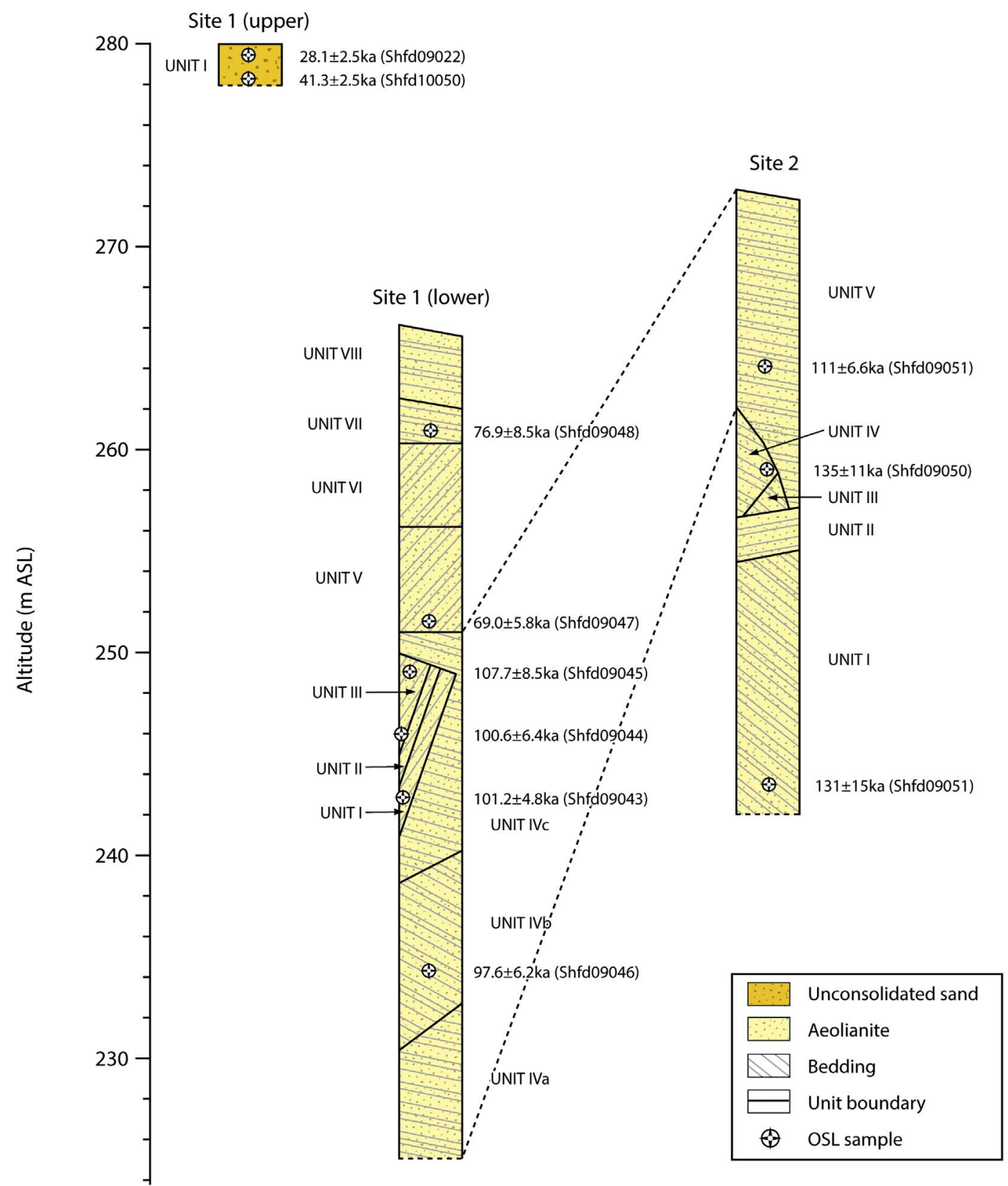

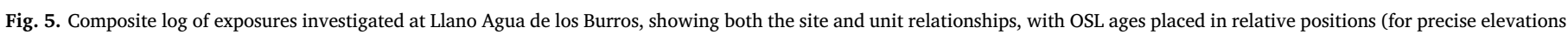
of OSL sampling sites see Table 5).

meteoric waters is therefore the most likely source (cf. Gardner and McLaren, 1993).

\subsection{Stable carbon and oxygen isotope data}

Stable carbon isotope ratios $\left(\delta^{13} \mathrm{C} \% 0_{\mathrm{VPDB}}\right)$ for bulk aeolianite samples from all three sites have an average value of $-0.32 \%$ ( $\pm 0.29 \%$ at $1 \mathrm{sd}$ ) and plot within a narrow range (1.1\%) (Fig. 9). Aeolianite stable oxygen isotope values $\left(\delta^{18} \mathrm{O} \%_{\mathrm{VPDB}}\right)$ range from $-0.75 \%$ to $+1.02 \%$, with an average of $+0.18 \pm 0.43 \%$. These are statistically identical to those obtained from the marine terrace carbonates, suggesting that the aeolianite has a strong marine isotopic signature (as evidenced in thin-section). A sample taken from the lower portion of the marine terrace at $27^{\circ} 54^{\prime} 40^{\prime \prime} \mathrm{S}, 071^{\circ} 05^{\prime} 40^{\prime \prime} \mathrm{W}$, for example, returned a $\delta^{13} \mathrm{C}$ value of $-0.76 \%$, whilst one marine terrace sample produced a $\delta^{18} \mathrm{O}$ value of $+0.52 \%$.

The narrow range exhibited by the aeolianite samples contrasts with the greater spread of lower isotopic values seen for samples collected from other sources. Pedogenic nodular carbonates, carbonate-coated clasts, and rhizoliths collected from the surface of the unconsolidated sands overlying the main aeolianite outcrop, have $\delta^{13} \mathrm{C}$ values between -1.17 and $-2.06 \%$. Well-developed carbonate samples collected at $1.3 \mathrm{~m}$ depth from within the unconsolidated sands, and from a $1.5 \mathrm{~m}$ exposed road cut, reveal values between -3.29 and $-4.13 \%$. Despite the predominance of $\mathrm{C}_{3}$ biomass at $\mathrm{LAB}$, which would produce values lower than $-9 \%$ (e.g. Cerling and Quade, 1993; see $\delta^{13} \mathrm{C}$ data in Table 4), the values for these carbonates are in fact, typical of soil carbonates from the Atacama Desert, as these are often enriched in ${ }^{13} \mathrm{C}$ by exchange with atmospheric $\mathrm{CO}_{2}$ due to very low plant cover (Quade et al., 2008). This is probably also the case for two vein calcite samples that formed within the aeolianite outcrop, which exhibit $\delta^{13} \mathrm{C}$ values between -2.5 to $-4.8 \%$. The $\delta^{18} \mathrm{O}$ values for samples of pedogenic origin exhibit a broad range (between -1.56 and $+2.05 \%$ ). These values are also commonly observed in carbonates of pedogenic origin in 
A Site 1: Units I- III

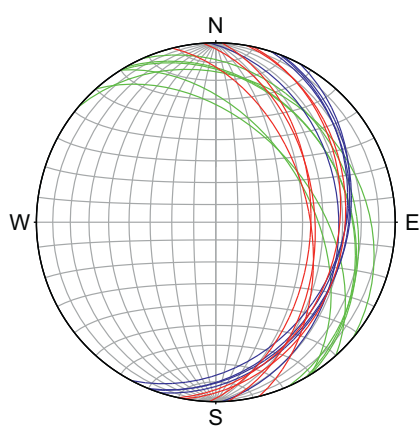

- Unit I _ Unit II _ Unit III
B Site 1: Units IVa - IVc

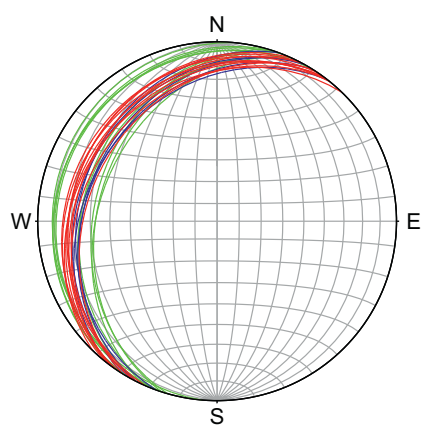

— Unit IVa — Unit IVb — Unit IVc

\section{Site 1: Units V - VIII}

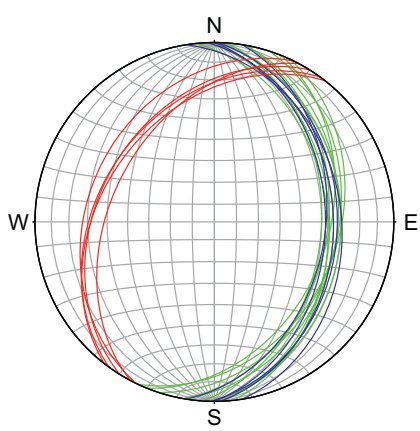

— Unit V — Unit VI — Unit VIII
D Site 2: Units I - IV

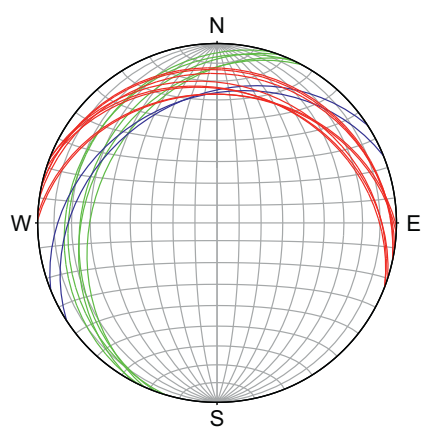

— Unit I U Unit III — Unit IV
$E$

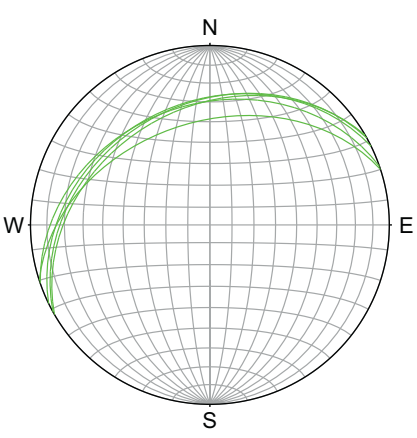

- Unit I

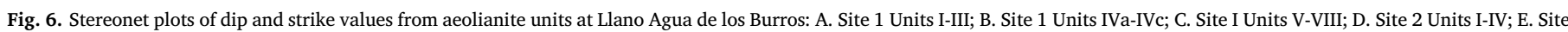
3 Unit 1 . Data are only plotted for units where the mean dip angle is $\geq 22^{\circ}$. See Table 1 and text for further information.

\section{Unit Sample Components}

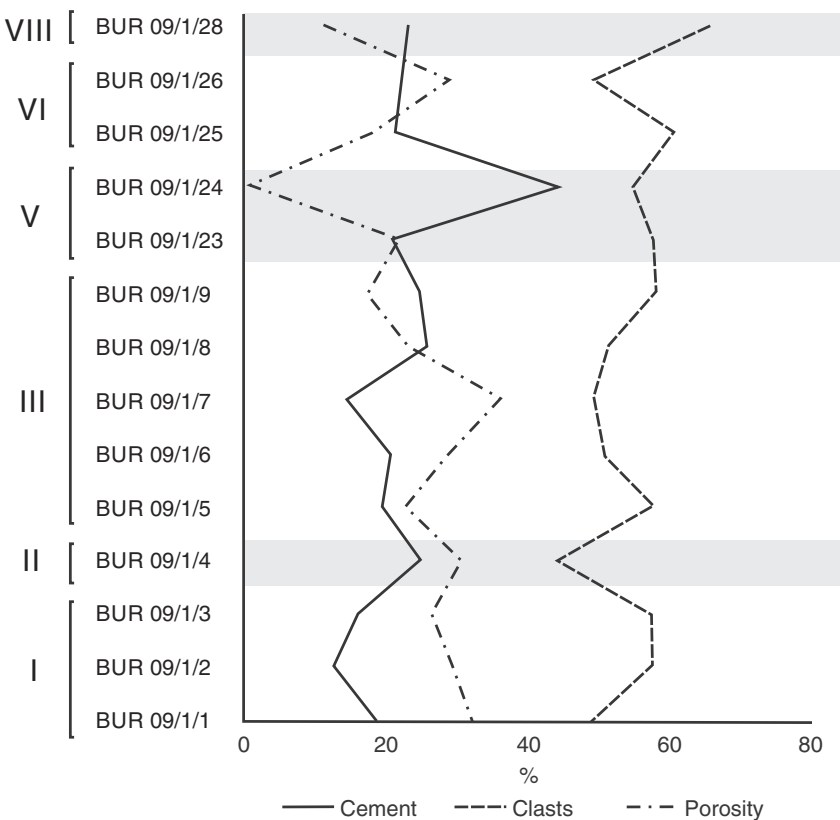

\section{Normalised cement types}

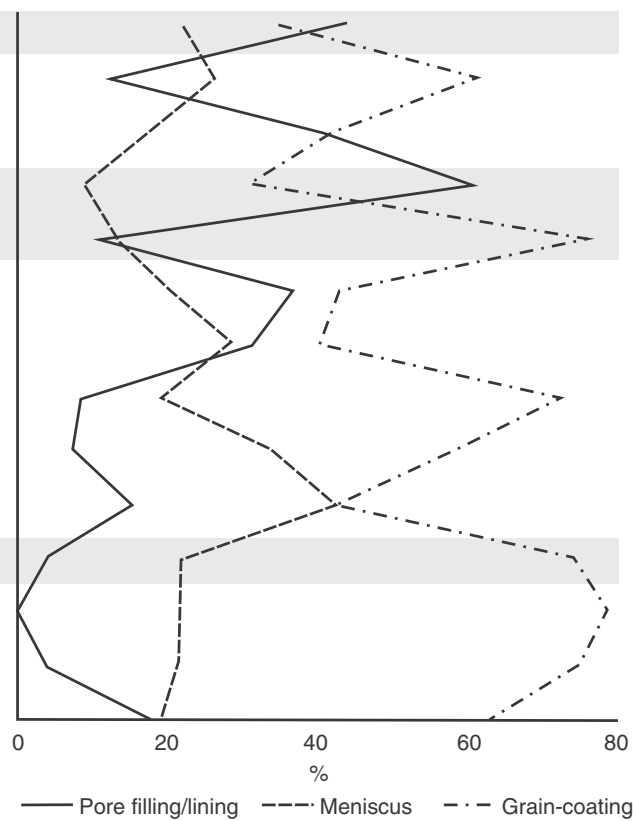

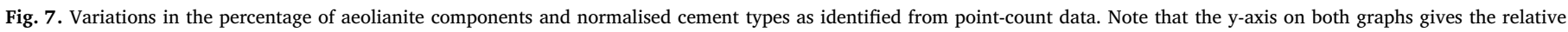
vertical position of samples and is not to scale. Shading used to differentiate different aeolianite units.

the Atacama, where high evaporation and atmospheric exchange are widespread processes due to the hyperaridity and very low percentage of plant cover (Quade et al., 2008).

\subsection{OSL dating}

Table 5 presents the OSL data results for the samples, with ages quoted from year of sampling (2009) with 1-sigma uncertainties. 

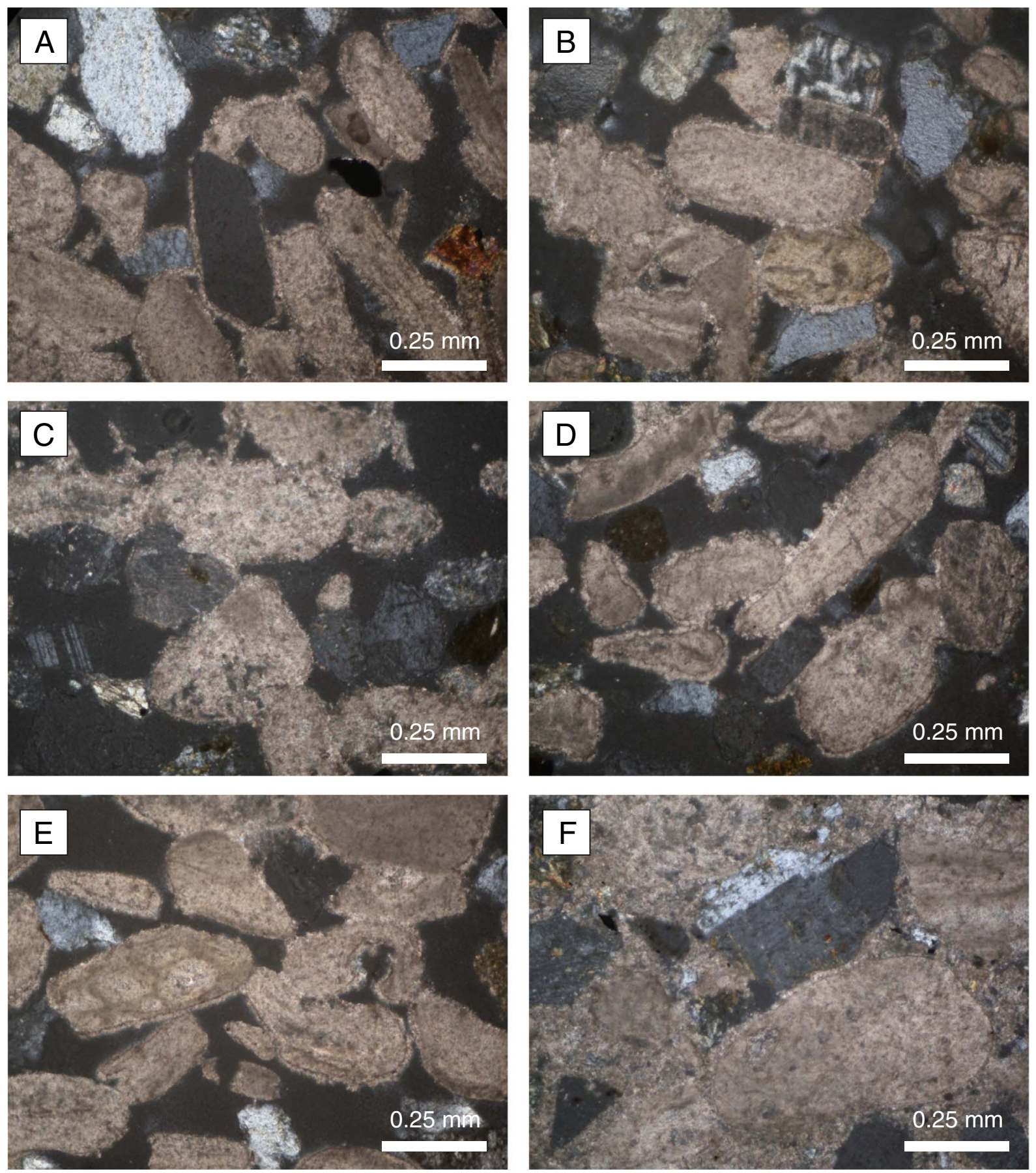

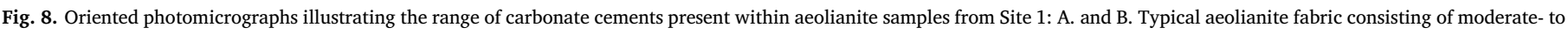

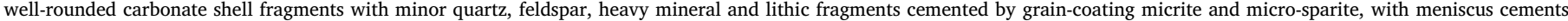

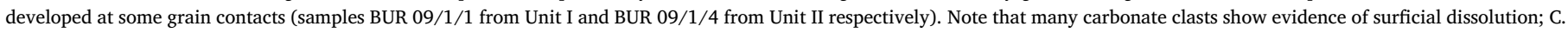

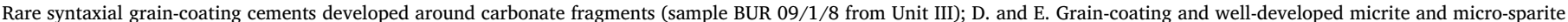

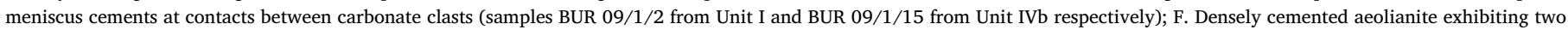

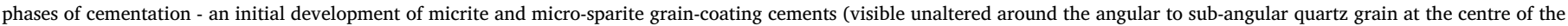

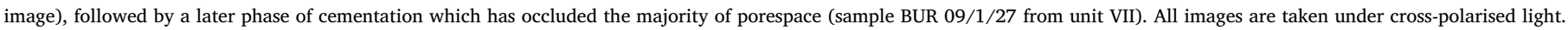

Despite the thickness of aeolianite, and multiple units with different bedding orientations, it would appear that many of the units were deposited within a relatively short time span, as ages are indistinguishable within errors. OSL ages fall into four phases of activity from 28 to $41 \mathrm{ka}$, 69-77 ka, 98-111 ka and at around $130 \mathrm{ka}$. The most recent of these from 28 to $41 \mathrm{ka}$ (MIS 3) is associated with the thin unconsolidated sand blanketing the top of the aeolianite sequence, which has ages of $28.1 \pm 2.5 \mathrm{ka}(\operatorname{Shfd09022)}$ and $41.3 \pm 2.5 \mathrm{ka}($ Shfd10050). A second phase appears to have occurred between 69 and 77 ka (the MIS 4/5 transition). This incorporates the uppermost aeolianite units at LAB Site 1 (Units V and VII). The phase between 98 and 111 ka (MIS 5b-5d) includes the lower aeolianites at LAB Site 1 (Units IVb, III and I) plus the youngest unit (Unit V) at LAB Site 2 . The earliest phase of aeolianite host sediment deposition is dated to ca.130 ka (MIS 5/6). This is recognised from the lower units (Units I and IV) at Site 2, from which two samples have ages of $131 \pm 15 \mathrm{ka}$ (Shfd09049) and $135 \pm 11 \mathrm{ka}$ 


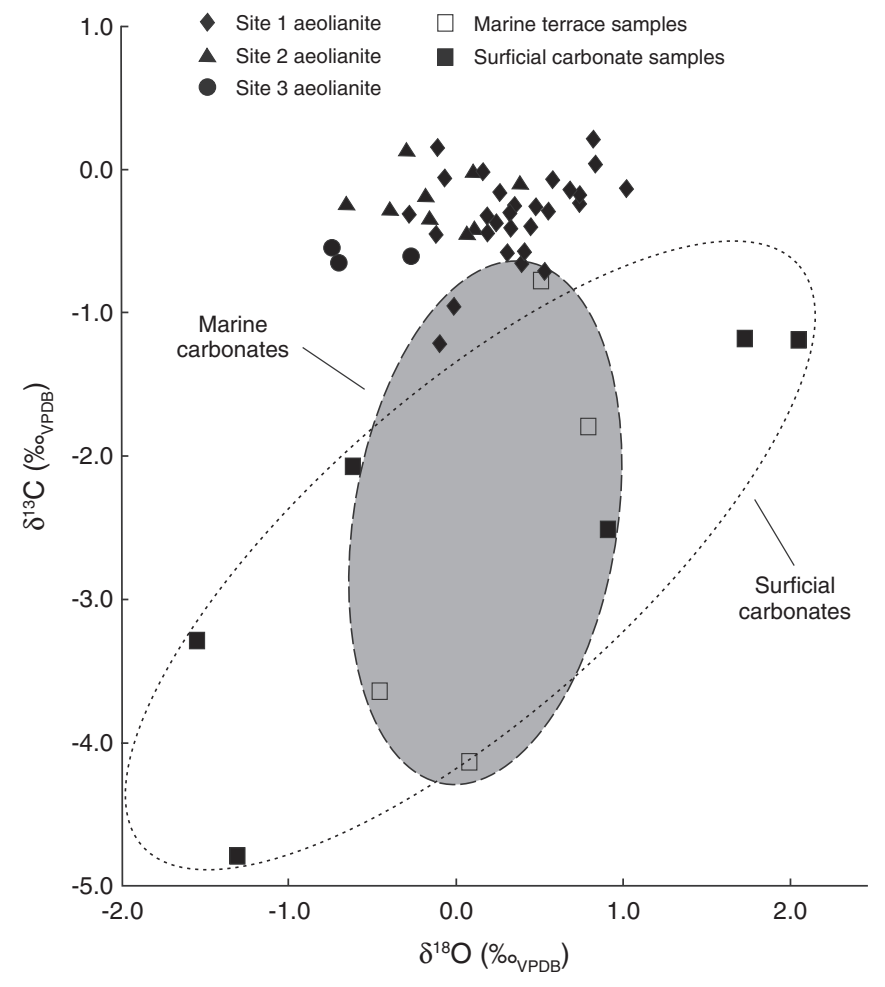

Fig. 9. Stable carbon and oxygen isotope data for aeolianite samples from sites $1-3$, together with selected marine terrace sediments and surficial carbonate nodules, and calcite veins from joints within the aeolianite outcrop at Site 1.

\section{(Shfd09050).}

\section{Discussion}

Isolating the factors that control the supply and preservation of aeolian sediments is critical in determining the past environmental significance of any site where aeolianite occurs. Such factors will now be considered for the study area, and their implications for our wider understanding of Atacama palaeoenvironments discussed.

\subsection{Sediment supply and eustatic sea-level change}

Thin-section analyses, coupled with stable $\mathrm{C}$ and $\mathrm{O}$ isotopic evidence, suggest a predominantly marine origin for the aeolianite host sediment at LAB. This contrasts with the well-dated Alto Ilo dune field in southern Peru, where sediment supply was from upwind alluvial fans, as well as from an extended coastal plain exposed as a result of lower eustatic sea level (Londoño et al., 2012). Optical dating shows further that the aeolianite host sediments at LAB were deposited in accommodation space at the front of the Sierra del Carrizo coastal range initially around $130 \mathrm{ka}$, with two subsequent phases at 98-111 and 69-77 ka (Figs. 10, 11). As Bateman et al. (2011) and Brooke et al. (2014) have demonstrated, the onshore deflation of coastal aeolian sediment to form dune systems (and ultimately coastal aeolianite) can be closely associated with changes in sea-level and offshore coastal platform topography. In the case of northern Chile, the initial phase of aeolian sediment deposition probably occurred during the marine transgression immediately preceding the MIS 5e sea-level maxima (Fig. 11D), with further deposition during the subsequent lower sealevel high stands following, or towards the end of, the last interglacial (i.e. MIS 5a and MIS 5c; Fig. 11E). It is likely that marine sediment moved initially landwards during phases of marine transgression and, given the steep offshore topography, was left as a sedimentary unit post-regression where the coastal topography allowed (e.g. Fig. 11A,
D). The low-lying embayment formed by the mouth and trunk valleys of the Quebrada Agua de los Burros, where cemented marine terrace sediments now occur up to $2.5 \mathrm{~km}$ inland from the contemporary coastline (Fig. 2A), may have provided a suitable location. Stranded marine sediment would have then been available for transportation by the wind to form the dunes banked up against the Sierra de Carrizo (cf. Segerstrom, 1962).

\subsection{Sediment supply and palaeowind variability}

The palaeowind data presented in Table 1 add further support to the Quebrada Agua de los Burros area being an important sediment source. The sediments within Units I, II, III, V and VI at Site 1, Units III and IV at Site 2 and Unit I at Site 3 are likely to have been moved from littoral sources by sand-transporting winds blowing from westerly to southwesterly directions. This is in line with the present-day low-level coastal wind regime (Fig. 3), which is dominated by the quasi-permanent PSTH (Muñoz and Garreaud, 2005). Given the configuration of the coastline and coastal mountain ranges, the sediments forming Units IV and VIII at Site 1 and Unit I at Site 2 can only have been deflated off the marine terrace to the south and southeast of LAB. At the present day, sandtransporting winds from the south occur only during austral autumn months (Fig. 3D). Sand-transporting winds from the southeast quadrant are extremely unusual, and may indicate either local topographic modification of airflow or larger scale atmospheric circulation changes. However, evidence from additional sites is needed before either of these propositions can be confirmed.

Assuming a fixed sediment source, particle size data suggest that average sand-transporting wind strengths were slightly higher during MIS 5e, the earliest phase of aeolianite host sediment deposition when Units I-IV at Site 2 accumulated. Sand-transporting wind directions also appear to have been relatively consistent at this time, ranging from $S$ to ESE (with possible allowances for topographic modification). Average wind strengths were lower, and wind directions more variable (WNW to ESE), during MIS 5a-5c when Units I-VII at Site 1 and Unit V at Site 2 accumulated. Lower wind speeds only capable of mobilising the finer sands, and/or a finer source of local sediments, are implied during MIS 3 when the unconsolidated sand blanketing the top of the aeolianite sequence was deposited.

The occurrence of winds of sufficient strength to accumulate tens of metres of sediment against the Sierra del Carrizo during MIS 5e, 5c and 5 a may reflect an intensification of atmospheric circulation. Contreras et al. (2010) have identified that reduced trade winds and weakened Walker circulation, resulting from a reduced thermal gradient across the equatorial Pacific, were behind the occurrence of a pluvial event in the northern Atacama during the LIG (MIS 5e). The remainder of MIS 5 was characterised by a more enhanced thermal gradient and, by inference, windier and/or stormier conditions. Aeolian sediment transport would have been optimal during this period and diminished in MIS 4. If the MIS 5 thermal gradient is representative of interglacial conditions then the phase of aeolianite host sediment deposition in MIS $5 \mathrm{c}$ may also reflect enhanced post-interglacial windiness and/or storminess.

Particle size data (Table 2) imply a potentially different source for the accumulation of wind-blown sediment during the latter stages of MIS 3. An increase in sediment discharge from coastal mountain ranges has been reported at this time (cf. Lamy et al., 1998), so sediment supply to the dune may have originated from the mountains inland of LAB (cf. Paskoff et al., 2003). This period of sediment accumulation falls within with one of the four phases of aeolian deposition identified in the Alto Ilo dunefield, Peru (Londoño et al., 2012).

\subsection{Tectonic uplift and sediment supply}

The relatively simple scenario described so far, whereby the aeolianite host sediments at $\mathrm{LAB}$ accumulated from interglacial marine 


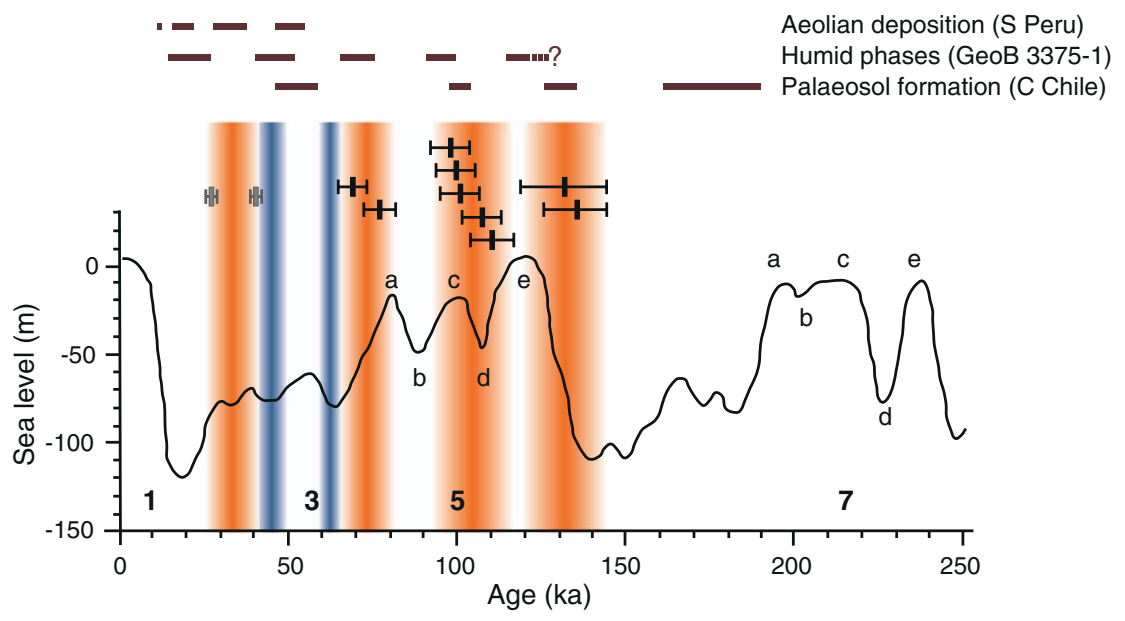

Fig. 10. Eustatic sea-level curve for the last $350 \mathrm{ka}$ (based on scaled benthic isotopes from marine core V19-30; Cutler et al., 2003), with OSL ages and error bars from this study superimposed. OSL ages in black are derived from aeolianite and those in grey from the windblown sand cover overlying the main aeolianite outcrop. Orange vertical bars indicate dune building phases. Blue vertical bars indicate proposed periods of aeolianite cementation. Also shown for comparison (brown horizontal bars) are phases of aeolian sediment deposition in the Alto Ilo dunefield, Peru (Londoño et al., 2012), humid periods inferred in marine core GeoB 3375-1 (Stuut and Lamy, 2004), and episodes of palaeosol development in central Chile (Veit et al., 2015). (For interpretation of the references to colour in this figure legend, the reader is referred to the web version of this article.) sediments that were deflated during windier intervals of MIS $5 \mathrm{e}, 5 \mathrm{c}$ and 5a (Fig. 11E), would be sufficient if the area was tectonically stable. However, as investigations of uplifted Late Pleistocene marine terraces exposed to the north and south of the study area attest, this is not the case.

Given that the earliest identified phase of dune deposition at LAB occurred from ca. $130 \mathrm{ka}$, the marine terrace at ca. $130 \mathrm{~m}$ asl maximum elevation underlying the study sites, and its associated deposits, must have been formed during or prior to MIS 5e. In the absence of radiometric dating of the terrace sediments and exposure dating of the terrace itself, it is not possible to be more precise at this stage. However, this minimum age fits well with inception dates for uplifted terraces elsewhere in northern Chile. Marine terraces correlated with MIS 11 are found at maximum elevations of $162 \mathrm{~m}$ and $139 \mathrm{~m}$ asl in the Caldera and Bahía-Inglesa areas respectively (Fig. 1B), to the north of LAB; a lower terrace at $115 \mathrm{~m}$ asl in the same areas is inferred to date from MIS 9 (Marquardt et al., 2004). Marine terraces (Saillard et al., 2009) and beach ridges (Saillard et al., 2012) dated to MIS 9 also occur at maximum elevations of $102 \mathrm{~m}$ and ca.114 $\mathrm{m}$ asl respectively in the Altos de Talinay/Tongoy Bay area to the south.

Terrace inception at LAB during MIS 9 (start date $334 \mathrm{ka}$ ) would indicate an average uplift rate for the study area of $390 \mathrm{~mm} \mathrm{kyr}^{-1}$. This is consistent with uplift rates for the Caldera/Bahía-Inglesa area $\left(280 \pm 50\right.$ and $450 \pm 60 \mathrm{~mm} \mathrm{kyr}^{-1}$ for the period MIS 11 to 1 ; Marquardt et al., 2004), and within the range identified for Altos de Talinay/Tongoy Bay (Saillard et al., 2009). Terrace formation during MIS 7 (start date $240 \mathrm{kyr}$ ) would indicate a higher uplift rate of $542 \mathrm{~mm} \mathrm{kyr}^{-1}$, closer to the rates of between $570 \pm 160$ and $700 \pm 40 \mathrm{~mm} \mathrm{kyr}^{-1}$ established by Saillard et al. (2011) for marine terraces in southern Peru.

Formation of the ca. $130 \mathrm{~m}$ asl marine terrace during interglacials preceding MIS 5e raises a potential question concerning the accumulation of sediments at LAB - namely, how was aeolian sediment supply maintained on a relatively rapidly uplifting coastal platform? The best answer to this is that sediment accumulated predominantly during sealevel highstands, with aeolian deflation occurring from the beach, and/ or from marine sediments deposited within the Quebrada Agua de los Burros embayment, and/or from the surface of the present-day ca. $130 \mathrm{~m}$ asl marine terrace, once sea-levels dropped. There must have been several phases of marine sediment accumulation, as it is unlikely that terrace sediments that had accumulated during MIS 7 (and/or 9) would have remained uncemented until MIS 5a. This is especially the case as wetter episodes have been identified in the intervening period (e.g. Stuut and Lamy, 2004; Jungers et al., 2013; Placzek et al., 2013; see Section 5.4), including a phase of palaeosol formation around La Serena (central Chile) during MIS 7 (Veit et al., 2015). Marine sediments may have accumulated additionally in the Quebrada Agua de los
Burros during a sea-level incursion in the early part of MIS 7 (Fig. 11A). Further marine sediments may have accumulated during MIS 5e (Fig. 11D), when eustatic sea-levels are thought to have been approximately $10 \mathrm{~m}$ higher compared to MIS 7 , and $15 \mathrm{~m}$ higher when compared to MIS 9 (Waelbroeck et al., 2002).

Ongoing tectonic uplift presents a further challenge for the aeolian transport of sediment from marine sources to the sites of aeolianite accumulation. Assuming that the sediments on the marine terrace were deposited originally in shallow $(<10 \mathrm{~m}$ ) water, the terrace (and by implication the three study sites) would have been uplifted by the time the earliest dated aeolianite host sediments were deposited. This would create a considerable vertical displacement between the site of aeolianite accumulation and any beach sediment source, with this displacement increasing over time. It is, however, possible for aeolian sediments to be transported to these sorts of elevations providing winds are sufficiently strong and intervening slope angles are $<45^{\circ}$ (cf. Jennings, 1967; Cooke et al., 1993; Saye et al., 2006; Muhs et al., 2014; Short, 2014). Indeed, the authors have observed active transverse dunes climbing to the top of the $>500 \mathrm{~m}$ asl high coastal cliffs near Iquique in northern Chile. Once sediment had been transported from the beach to the marine terrace, it could then have served as a supply for the aeolian sediments at $\mathrm{LAB}$.

\subsection{Aeolianite cementation during wetter climatic intervals}

Thin section analyses indicate that the majority of aeolianite samples exhibit a single main phase of carbonate cementation. Many samples from the upper units at LAB Sites 1 and 2 also contain evidence of a second, later, phase of cementation that partially or completely infilled remaining pore space. It is not possible to estimate the moisture input required for each cementation phase. However, the partial dissolution of shell materials inferred as the source for the first generation cements is likely to have required the greater volume of percolating water. That the MIS 5e host sediments at Site 2 are no more extensively cemented than the MIS $5 \mathrm{a}-5 \mathrm{c}$ deposits from Site 1 suggests that cementation began at some point after $70 \mathrm{ka}$ (the age of the youngest aeolianite host sediments). In the absence of radiometric dating of the cement phases, it is only possible to speculate when this occurred, but cementation must have taken place prior to the erosional event(s) that led to the fluvial dissection of the main aeolianite outcrop.

Palaeoenvironmental sequences for the Atacama extending back to the LIG are very rare. The aridity index derived for marine core GeoB 3375-1 (Lamy et al., 1998, 2000; Stuut and Lamy, 2004) is the closest long record to the study area. Caution is needed in interpreting this index as only the age model for the period up to $40 \mathrm{ka}$ is based upon radiometric dating (Lamy et al., 1998, 2000); earlier parts of the record are tuned to the SPECMAP $\delta^{18} \mathrm{O}$ stack (Imbrie et al., 1984), and Berger 
A MIS 7e: Interglacial Highstand Maximum Sediment moved onshore Marine terrace formation

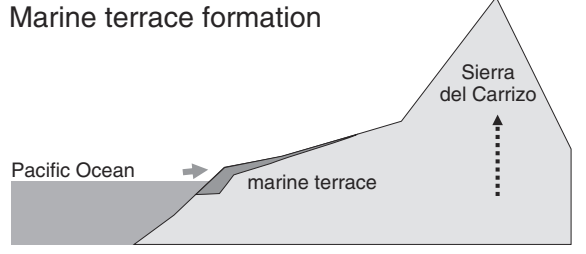

C MIS 6: Glacial Lowstand

Sea level down to minimum Prolonged uplift

Erosion of marine terrace

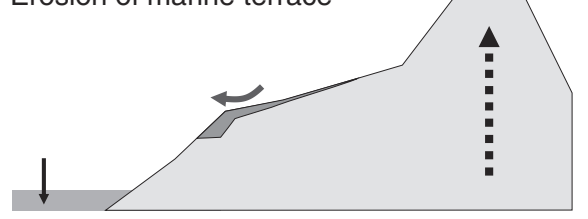

E MIS 5e, 5c and 5a: Post-Interglacial Highstand

Sea level falling

Dune building

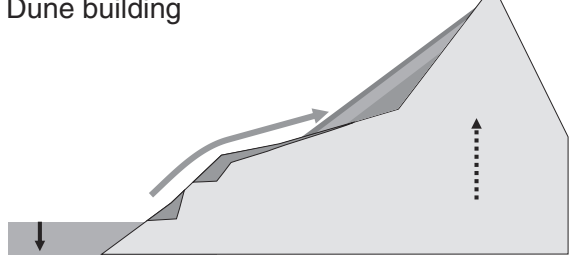

G End-MIS 3 to MIS 2: Glacial Lowstand Sea level down to minimum

Sediment from mountain/terrace surfaces

Dissection of aeolianite

Dune building

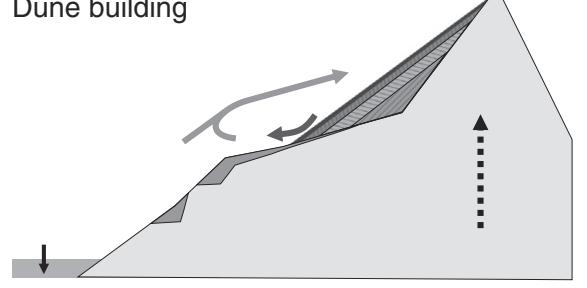

B MIS 7d-7a: Post-Interglacial Highstand Sea level falling

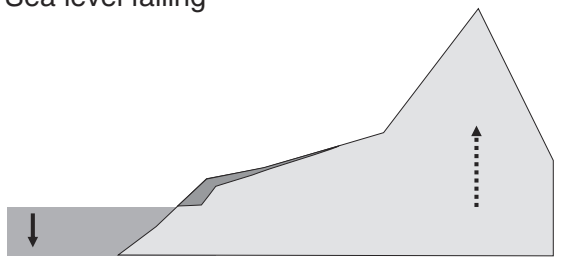

D Early MIS 5e: Interglacial Highstand Maximum

Sediment moved onshore Marine terrace formation

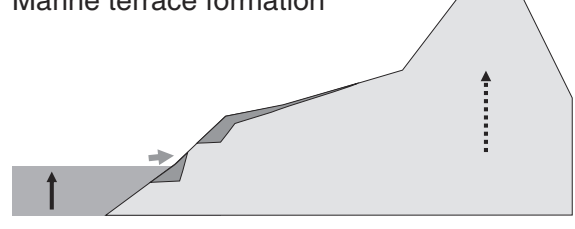

\section{F MIS 4 to 3: Glacial}

Sea level falling

Prolonged uplift

Aeolianite cementation phases

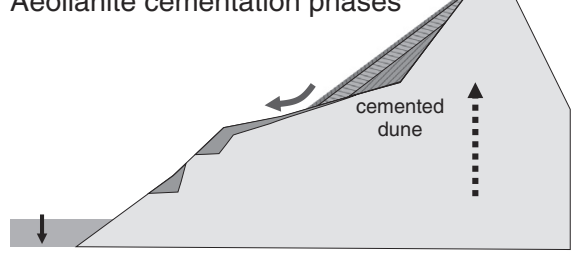

H MIS 1: Interglacial Highstand Maximum

Sediment moved onshore

Marine terrace formation

Further dissection of aeolianite

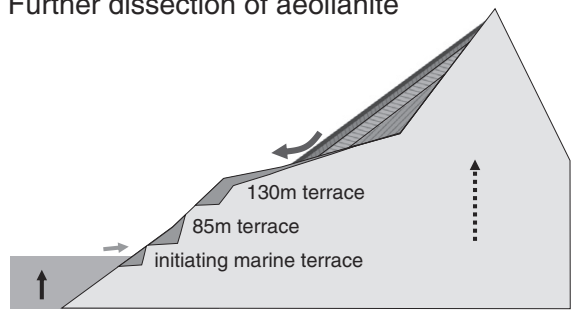

Fig. 11. (A-H) Conceptual diagram showing the phases of marine terrace development, dune building, aeolianite cementation and landscape dissection at Llano Agua de los Burros from MIS $7-$ 1. Pale grey arrows indicate onshore sediment movement by marine and aeolian processes. Dark grey arrows indicate surface erosion and sediment transport by fluvial processes. Solid black arrows indicate rising or falling sea level. Dashed black arrows indicate uplift, with arrow size reflecting the relative magnitude of uplift over time. Note that the dimensions of terraces and aeolian sediments are schematic only and not to scale. (For interpretation of the references to colour in this figure legend, the reader is referred to the web version of this article.) and Loutre (1991) precession index. The GeoB 3375-1 aridity index indicates five humid periods in the near-coastal Atacama since the LIG. The first, centred around $120 \mathrm{ka}$, coincides with evidence for increased summer rainfall over the Bolivian Altiplano (Placzek et al., 2013) and at ODP Site 1229 off Peru (Contreras et al., 2010), and palaeosol development in central Chile (Veit et al., 2015), suggesting a widespread wetter LIG. The second, centred around $90 \mathrm{ka}$, and immediately following the second phase of aeolianite sediment deposition at LAB, coincides with a short-lived wetter episode in the Bolivian Altiplano (Placzek et al., 2013) and a phase of palaeosol development in central Chile (Veit et al., 2015). The third (ca.70 ka) is synchronous with highstands in the Salar de Atacama (Bobst et al., 2001) and Salar de Uyuni (Fritz et al., 2004); however, this humid phase is not identified in the Bolivian Altiplano record of Placzek et al. (2013), and was not associated with palaeosol development in central Chile (Veit et al., 2015). The fourth (ca. $45 \mathrm{ka}$ ), coincides with high-stands in both the Salar de Atacama and Salar de Uyuni (Bobst et al., 2001; Fritz et al., 2004), wetter conditions across the southern Bolivian Altiplano (Placzek et al., 2013), palaeosol development in central Chile (Veit et al., 2015), and with palaeoecological evidence for increased rainfall in the Andean cordillera (e.g. Latorre et al., 2002; Maldonado et al., 2005; Quade et al., 2008; Mujica et al., 2015). The most recent humid phase, during the last glacial-interglacial transition, includes the Central Andean (or Atacama) Pluvial Event noted in Section 1.

Given that there are two main phases of cementation within the LAB aeolianite post-MIS $5 \mathrm{a}$, it is tempting to infer that the first occurred around $70 \mathrm{ka}$ and the second ca. $45 \mathrm{ka}$ (Figs. 10, 11F). This was followed by the deposition of the unconsolidated cover sands between 41 and 28 ka (Fig. 11G), with sediment potentially sourced from the mountains inland of LAB where conditions may have been wetter. This phase of deposition is also coincident with the accumulation of aeolian sediments in the Alto Ilo dunefield to the north (Londoño et al., 2012). Several studies point to a phase of enhanced regional moisture during the LGM in north-central Chile, attributed to a northward shift in the 
westerly wind belt (Denton et al., 1999; Heusser et al., 1999; Lamy et al., 1999; Hebbeln et al., 2002; Shulmeister et al., 2004; Maldonado et al., 2005). This has been linked to Antarctic sea-ice extent (Lamy et al., 2004; Stuut et al., 2004; Kaiser et al., 2005). It is feasible that the wet conditions associated with this period led to the dissection of the main aeolianite outcrop (Fig. 11G).

\section{Conclusions}

The analysis of aeolianites, unconsolidated aeolian sediments, surficial carbonates and marine terrace remnants from the Llano Agua de los Burros area of north-central Chile has yielded a record of environmental change for the coastal southern Atacama Desert spanning the last glacial-interglacial cycle. In summary, our results indicate:

- On the basis of OSL dating, aeolianite host sediments were deposited in three main episodes during the last interglacial and glacial period, at ca.130 ka (MIS 6b/5e), 111-98 ka (MIS 5d-5b) and 77-69 ka (MIS 5a-4b);

- Thin-section and stable $\mathrm{C}$ and $\mathrm{O}$ isotope analyses imply a predominantly marine source for these host sediments;

- Bedding orientations within the aeolianite indicate that sandtransporting winds varied, at least at a local scale, in direction from $S$ to ESE during MIS $5 \mathrm{e}$ and from WNW to ESE during MIS $5 c-5 a$, a considerably greater range than occurs at the present day;

- Thin-section evidence indicates two phases of aeolianite cement accumulation, the first (possibly ca.70 ka) from partial dissolution of shell material by percolating meteoric water, the second less pervasive (possibly ca.45 ka) from percolating meteoric water alone;

- A later phase of aeolian activity occurred between 41 and $28 \mathrm{ka}$ (MIS 3) and was possibly sourced in part by fluvially-derived sediments during a period of increased rainfall in the Andes;

- Uplift of the coastal platform has proceeded at an average rate of 305 to $542 \mathrm{~mm} \mathrm{kyr}^{-1}$.

This study illustrates the complexity of understanding onshore-offshore sediment transitions for an area experiencing both large Late Quaternary sea-level fluctuations and rapid tectonic uplift. Within this context, 'windows of opportunity' clearly occurred when sediment delivery, sediment availability, land surfaces over which windblown sediment could be transported, winds sufficient to transport this sediment, barriers against which dunes could form and, finally, conditions conducive to cement aeolianite existed. All these factors came together at times since MIS 9 to form and retain the carbonate aeolianite at Llano Agua de los Burros. Unlike aeolianites on the Coorong coastal plain in southern Australia (e.g. Murray-Wallace et al., 2010), uplift through time, combined with a narrow, steeply shelving coastal platform backed by mountains, prevented multiple barriers of dunes forming at LAB, since accommodation space remained broadly static. Likewise, the tectonic stability and dense coastal vegetation that promoted the stacking of aeolianites from multiple interglacials in South Africa and most of Australia (e.g. Porat and Botha, 2008; Bateman et al., 2011) does not apply at LAB. Instead, preservation occurred due to rapid lithification after sediment deposition and, unlike KwaZulu Natal, limited post-depositional chemical weathering due to regional aridity. Uplift appears to have eventually removed dunes vertically from their sediment source(s), providing a limit to the timespan that a single deposit can encompass, even with good preservation.

The challenge for future work in western South America is to identify and investigate other aeolianite outcrops - if they occur at this scale - along this section of tectonically-active coastline, to substantiate whether the conditions we identify were localised or regional. Of particular significance would be if regional long-term palaeowind records could be established to evaluate changes through time in the position and strength of the PSTH and/or the Walker Cell that drive the trade winds.

\section{Acknowledgements}

This research was funded by the National Geographic Society (Research Grant 8493-08); by CONICYT (grant PFB-23) to the IEB; with additional support from the University of Brighton, University of Sheffield, and Loughborough University. Thin section preparation was undertaken at the Open University and Royal Holloway (University of London). Stable oxygen and carbon analyses were also carried out at Royal Holloway. Mark Szegner is thanked for his assistance with the drafting of Figs. 1 and 3, and David McCutcheon with the drafting of Fig. 6.

\section{Appendix A. Supplementary data}

Supplementary data to this article can be found online at https:// doi.org/10.1016/j.palaeo.2017.11.040.

\section{References}

Adamiec, G., Aitken, M.J., 1998. Dose-rate conversion factors update. Ancient TL 16, $37-50$.

Andreucci, S., Clemmensen, L.B., Murray, A., Pascucci, V., 2010. Middle to late Pleistocene coastal deposits of Alghero, northwest Sardinia (Italy): chronology and evolution. Quat. Int. 222, 3-16.

Araya Vergara, J.F., 2001. Los ergs del desierto marginal de Atacama. Investigaciones Geográficos de Chile 35, 27-66.

Ballarini, M., Wallinga, J., Wintle, A.G., Bos, A.J.J., 2007. A modified SAR protocol for optical dating of individual grains from young quartz samples. Radiat. Meas. 42, 360-369.

Bateman, M.D., Catt, J.A., 1996. An absolute chronology for the raised beach deposits at Sewerby, E. Yorkshire, UK. J. Quat. Sci. 11, 389-395.

Bateman, M.D., Boulter, C.H., Carr, A.S., Frederick, C.D., Peter, D., Wilder, M., 2007. Detecting post-depositional sediment disturbance in sandy deposits using optical luminescence. Quat. Geochronol. 2, 57-64.

Bateman, M.D., Carr, A.S., Dunajko, A., Holmes, P.J., Roberts, D.L., McLaren, S.J., Bryant, R.G., Marker, M.E., Murray-Wallace, C.V., 2011. The evolution of coastal barrier systems: a case study of the middle-late Pleistocene wilderness barriers, South Africa. Quat. Sci. Rev. 30, 63-81.

Berger, A., Loutre, M.F., 1991. Insolation values for the climate of the last 10 million years. Quat. Sci. Rev. 10, 297-317.

Betancourt, J.L., Latorre, C., Rech, J.A., Quade, J., Rylander, K.A., 2000. A 22,000-year record of monsoonal precipitation from northern Chile's Atacama Desert. Science 289, 1542-1546.

Blanco, N., Godoy, E., Marquardt, C., 2003. Cartas Castilla y Totoral Bajo, Región de Atacama. In: Carta Geológica de Chile. Serie Geological Básica number 77 and 78 Servicio Nacional de Geología y Minería (Chile), Santiago.

Bobst, A.L., Lowenstein, T.K., Jordan, T.E., Godfrey, L.V., Ku, T.-L., Luo, S., 2001. A 106 ka paleoclimate record from drill core of the Salar de Atacama, northern Chile. Palaeogeogr. Palaeoclimatol. Palaeoecol. 173, 21-42.

Brooke, B., 2001. The distribution of carbonate eolianite. Earth Sci. Rev. 55, 135-164.

Brooke, B.P., Olley, J.M., Pietsch, T., Playford, P.E., Haines, P.W., Murray-Wallace, C.V., Woodroffe, C.D., 2014. Chronology of Quaternary coastal aeolianite deposition and the drowned shorelines of southwestern Western Australia - a reappraisal. Quat. Sci. Rev. 93, 106-124.

Bullard, J.E., 1997. A note on the use of the "Fryberger method" for evaluating potential sand transport by wind. J. Sediment. Res. 67, 499-501.

Castro Avaria, C., Zúñiga Donoso, Á., Pattillo Barrientos, C., 2012. Geomorfología y geopatrimonio del Mar de Dunas de Atacama, Copiapó (27S), Chile. Revista de Geografía Norte Grande 53, 123-136.

Cawthra, H.C., Bateman, M.D., Carr, A.S., Compton, J.S., Holmes, P.J., 2014. Understanding late Quaternary change at the land-ocean interface: a synthesis of the evolution of the Wilderness Coastline, South Africa. Quat. Sci. Rev. 99, 210-223.

Cerling, T.E., Quade, J., 1993. Stable carbon and oxygen isotopes in soil carbonates. In: Swart, P.K., Lohmann, K.C., Mckenzie, J., Savin, S. (Eds.), Climate Change in Continental Isotopic Records. American Geophysical Union, Washington, D.C., pp. 217-231.

Cerveny, R., 1998. Present climates of South America. In: Hobbs, J.E. (Ed.), Climates of the Southern Continents: Present, Past and Future. John Wiley and Sons, Chichester, UK, pp. 107-135.

Chauhan, N., Singhvi, A.K., 2011. Distribution in SAR palaeodoses due to spatial heterogeniety of natural beta dose. Geochronometrica 38, 190-198.

Contreras, S., Lange, C.B., Pantoja, S., Lavik, G., Rincón-Martínez, D., Kuypers, M.M.M., 2010. A rainy northern Atacama Desert during the last interglacial. Geophys. Res. Lett. 37, Ll23612.

Contreras-Reyes, E., Becerra, J., Kopp, H., Reichert, C., Díaz-Naveas, J., 2014. Seismic structure of the north-central Chilean convergent margin: subduction erosion of a paleomagmatic arc. Geophys. Res. Lett. 41, 1523-1529.

Cooke, R.U., Warren, A., Goudie, A.S., 1993. Desert Geomorphology. UCL Press, London.

Cutler, K.B., Edwards, R.L., Taylor, F.W., Cheng, H., Adkins, J., Gallup, C.D., Cutler, P.M., Burr, G.S., Bloom, A.L., 2003. Rapid sea-level fall and deep-ocean temperature 
change since the last interglacial period. Earth Planet. Sci. Lett. 206, 253-271.

De Porras, M.E., Maldonado, A., De Pol-Holz, R., Latorre, C., Betancourt, J., 2017. Late Quaternary environmental dynamics in the Atacama Desert reconstructed from rodent midden pollen records. J. Quat. Sci. 32, 665-684.

Denton, G.H., Heusser, C.J., Lowell, T.V., Moreno, P.I., Andersen, B.G., Heusser, L.E., Schluchter, C., Marchant, D.R., 1999. Interhemispheric linkage of palaeoclimate during the last glaciation. Geografiska Annaler. Series A - Phys. Geogr. 81A, 107-153.

Díaz, F.P., Latorre, C., Maldonado, A., Quade, J., Betancourt, J.L., 2012. Rodent middens reveal episodic, long distance plant colonizations across the hyperarid Atacama Desert over the last 34,000 years. J. Biogeogr. 39, 510-525.

Dravis, J.J., 1996. Rapidity of freshwater calcite cementation - implications for carbonate diagenesis and sequence stratigraphy. Sediment. Geol. 107, 1-10.

Eastwood, E.N., Kocurek, G., Mohrig, D., Swanson, T., 2012. Methodology for reconstructing wind direction, wind speed and duration of wind events from aeolian cross-strata. J. Geophys. Res. 117, F03035. http://dx.doi.org/10.1029/ 2012JF002368.

Fairbridge, R.W., 1995. Eolianites and eustasy: early concepts on Darwin's voyage of HMS Beagle. Carbonates Evaporites 10, 92-101.

Finkel, H., 1959. The barchans of southern Peru. J. Geol. 67, 614-647.

Flores-Aqueveque, V., Alfaro, S., Muñoz, R., Rutllant, J.A., Caquineau, S., Le Roux, J.P., Vargas, G., 2010. Aeolian erosion and sand transport over the Mejillones Pampa in the coastal Atacama Desert of northern Chile. Geomorphology 120, 312-325.

Folk, R.L., Ward, W.C., 1957. Brazos River bar, a study in the significance of grain-size parameters. J. Sediment. Petrol. 27, 3-27.

Fritz, S.C., Baker, P.A., Lowenstein, T.K., Seltzer, G.O., Rigsby, C.A., Dwyer, G.S., Tapia, P.M., Arnold, K.K., Teh-Lung Ku, T.-L., Luo, S., 2004. Hydrologic variation during the last 170,000 years in the southern hemisphere tropics of South America. Quat. Res. 61, 95-104.

Fryberger, S., 1979. Dune forms and wind regime. In: McKee, E.D. (Ed.), A Study of Global Sand Seas. US Geological Survey Professional Paper Vol. 1052. pp. 137-169.

Fuenzalida, H.A., Sanchez, R., Garreaud, R.D., 2005. A climatology of cutoff lows in the Southern Hemisphere. J. Geophys. Res.-Atmos. 110, D18101. http://dx.doi.org/10. 1029/2005JD005934.

Galbraith, R.F., Roberts, R.G., Laslett, G.M., Yoshida, H., Olley, J.M., 1999. Optical dating of single and multiple grains of quartz from Jinmium rock shelter, northern Australia: part I, experimental design and statistical models. Archaeometry 41, 339-364.

Gardner, R.A.M., McLaren, S.J., 1993. Progressive vadose diagénesis in late Quaternary aeolianite deposits. In: Pye, K. (Ed.), The Dynamics and Environmental Context of Aeolian Sedimentary Systems. Geological Society Special Publication 72 Geological Society, London, pp. 219-234.

Garreaud, R., 2009. The Andes climate and weather. Adv. Geosci. 7, 1-9.

Garreaud, R., Aceituno, P., 2002. Atmospheric circulation over South America: mean features and variability. In: Veblen, T., Young, K., Orme, A. (Eds.), The Physical Geography of South America. Oxford University Press, Oxford, pp. 45-59.

Gay, S.P., 1962. Origen, distribución y movimiento de las arenas eólicas en el área de Yauca a Palpa. Boletín de la Sociedad Geológica del Perú 37, 37-58.

Gay, S.P., 1999. Observations regarding the movement of barchan sand dunes in the Nazca to Tanaca area of southern Peru. Geomorphology 27, 279-293.

Gayo, E.M., Latorre, C., Jordan, T.E., Nester, P.L., Estay, S.A., Ojeda, K.F., Santoro, C.M., 2012. Late Quaternary hydrological and ecological changes in the hyperarid core of the northern Atacama Desert ( $\sim 21^{\circ}$ S). Earth Sci. Rev. 113, 120-140.

Gutscher, M.A., Spakman, W., Bijwaard, H., Engdahl, E.R., 2000. Geodynamics of flat subduction: seismicity and tomographic constraints from the Andean margin. Tectonics 19, 814-833.

Hastenrath, S.L., 1967. The barchans of the Arequipa region, southern Peru. Z. Geomorphol. 11, 300-311.

Hastenrath, S.L., 1987. The barchans of southern Peru revisited. Z. Geomorphol. 31, 167-178.

Hebbeln, D., Marchant, M., Wefer, G., 2002. Paleoproductivity in the southern Peru-Chile current through the last 33,000 years. Mar. Geol. 186, 487-504.

Hesse, R., 2009a. Do swarms of migrating barchan dunes record paleoenvironmental changes? A case study spanning the middle to late Holocene in the Pampa de Jaguay, southern Peru. Geomorphology 104, 185-190.

Hesse, R., 2009b. Using remote sensing to quantify aeolian transport and estimate the age of the terminal dune field Dunas Pampa Blanca in southern Peru. Quat. Res. 71, 426-436.

Heusser, L., Heusser, C.J., Kleczkowski, A., Crowhurst, S., 1999. A 50,000-yr pollen record from Chile of South American millennial-scale climate instability during the last glaciation. Quat. Res. 52, 154-158.

Imbrie, J., Hays, J.D., Martinson, D.G., McIntyre, A., Mix, A.C., Morley, J.J., Pisias, N.G., Prell, W.L., Shackleton, N.J., 1984. The orbital theory of Pleistocene climate: support from a revised chronology of the marine $\delta^{18} \mathrm{O}$ record. In: Berger, A., Imbrie, J., Hays, H., Kukla, G., Saltzman, B. (Eds.), Milankovitch and Climate. Part 1. Reidel, Norwell, Massachusetts, pp. 269-305.

Jennings, J.N., 1967. Cliff-top dunes. Aust. Geogr. Stud. 5, 40-49.

Jungers, M.C., Heimsath, A.M., Amundson, R., Balco, G., Shuster, D., Chong, G., 2013. Active erosion-deposition cycles in the hyperarid Atacama Desert of northern Chile. Earth Planet. Sci. Lett. 371-372, 125-133.

Kaiser, J., Lamy, F., Hebbeln, D., 2005. A 70-kyr sea surface temperature record off southern Chile (ocean drilling program site 1233). Paleoceanography 20, PA4009. http://dx.doi.org/10.1029/2005PA001146.

Kaiser, J., Schefuß, E., Lamy, F., Mohtadi, M., Hebbeln, D., 2008. Glacial to Holocene changes in sea surface temperature and coastal vegetation in north central Chile: high versus low latitude forcing. Quat. Sci. Rev. 27, 2064-2075.

Kocurek, G., Townsley, M., Yeh, E., Havholm, K., Sweet, M.L., 1992. Dune and dune-field development on Padre Island, Texas, with implications for interdune deposition and water-table-controlled accumulation. J. Sediment. Petrol. 62, 622-635.

Lamy, F., Hebbeln, D., Wefer, G., 1998. Late Quaternary precessional cycles of terrigenous sediment input off the Norte Chico, Chile $\left(27.5^{\circ} \mathrm{S}\right)$ and palaeoclimatic implications. Palaeogeogr. Palaeoclimatol. Palaeoecol. 141, 233-251.

Lamy, F., Hebbeln, D., Wefer, G., 1999. High-resolution marine record of climatic change in mid-latitude Chile during the last 28,000 years based on terrigenous sediment parameters. Quat. Res. 51, 83-93.

Lamy, F., Klump, J., Hebbeln, D., Wefer, G., 2000. Late Quaternary rapid climate change in northern Chile. Terra Nova 12, 8-13.

Lamy, F., Kaiser, J., Ninnemann, U., Hebbeln, D., Arz, H.W., Stoner, J., 2004. Antarctic timing of surface water changes off Chile and Patagonian ice sheet response. Science 304, 1959-1962.

Latorre, C., Betancourt, J.L., Rylander, K.A., Quade, J., 2002. Vegetation invasions into absolute desert: a 45,000 yr rodent midden record from the Calama-Salar de Atacama basins, northern Chile (lat 22-24 S). Geol. Soc. Am. Bull. 114, 349-366.

Latorre, C., Betancourt, J.L., Rylander, K.A., Quade, J., Matthei, O., 2003. A vegetation history from the arid prepuna of northern Chile $\left(22-23^{\circ} \mathrm{S}\right)$ over the last 13,500 years. Palaeogeogr. Palaeoclimatol. Palaeoecol. 194, 223-246.

Latorre, C., Betancourt, J.L., Arroyo, M.T.K., 2006. Late Quaternary vegetation and climate history of a perennial river canyon in the Rio Salado basin $\left(22^{\circ} \mathrm{S}\right)$ of northern Chile. Quat. Res. 65, 450-466.

Latorre, C., Moreno, P.I., Vargas, G., Maldonado, A., Villa-Martínez, R., Armesto, J.J., Villagrán, C., Pino, M., Núñez, L., Grosjean, M., 2007. Late Quaternary environments and palaeoclimate. In: Moreno, T., Gibbons, W. (Eds.), The Geology of Chile. The Geological Society, London, pp. 309-328.

Latorre, C., González, A.L., Quade, J., Fariña, J.M., Pinto, R., Marquet, P.A., 2011. Establishment and formation of fog-dependent Tillandsia landbeckii dunes in the Atacama Desert: evidence from radiocarbon and stable isotopes. J. Geophys. Res. 116, G03033. http://dx.doi.org/10.1029/2010JG001521.

Latorre, C., Santoro, C.M., Ugalde, P.C., Gayo, E.M., Osorio, D., Salas-Egaña, C., De Pol Holz, R., Joly, D., Rech, J.A., 2013. Late Pleistocene human occupation of the hyperarid core in the Atacama Desert, northern Chile. Quat. Sci. Rev. 77, 19-30.

Le Roux, J.P., Gómez, C., Venegas, C., Fenner, J., Middleton, H., Marchant, M., Buchbinder, B., Frassinetti, D., Marquardt, C., Gregory-Wodzicki, K.M., Lavenu, A., 2005. Neogene-Quaternary coastal and offshore sedimentation in north central Chile: record of sea-level changes and implications for Andean tectonism. J. S. Am. Earth Sci. 19, 83-98.

Leighton, C.L., Bailey, R.M., Thomas, D.S.G., 2013. The utility of desert sand dunes as Quaternary chronostratigraphic archives: evidence from the northeast Rub' al Khali. Quat. Sci. Rev. 78, 303-318.

Londoño, A.C., Forman, S.L., Eichler, T., Pierson, J., 2012. Episodic eolian deposition in the past ca. 50,000 years in the Alto Ilo dune field, southern Peru. Palaeogeogr. Palaeoclimatol. Palaeoecol. 346-347, 12-24.

Maldonado, A., Villagrán, C., 2002. Paleoenvironmental changes in the semiarid coast of Chile $\left(\sim 32^{\circ} \mathrm{S}\right)$ during the last $6200 \mathrm{cal}$ years inferred from a swamp-forest record. Quat. Res. 58, 130-138.

Maldonado, A., Villagrán, C., 2006. Climate variability over the last 9900 cal yr BP from a swamp forest pollen record along the semiarid coast of Chile. Quat. Res. 66, 246-258.

Maldonado, A., Betancourt, J.L., Latorre, C., Villagrán, C., 2005. Pollen analyses from a 50000 -yr rodent midden series in the southern Atacama Desert ( $\left.25^{\circ} 30^{\prime} \mathrm{S}\right)$. J. Quat. Sci. 20, 493-507.

Marchant, M., 2000. Micropaleontología del área entre Caleta Obispito y Quebrada Agua de los Burros, III Región. Informe (Inédito). Servicio Nacional de Geología y Mineríauniversidad de Concepción.

Marquardt, C., Lavenu, A., Ortlieb, L., Godoy, E., Comte, D., 2004. Coastal neotectonics in southern Central Andes: uplift and deformation of marine terraces in northern Chile (27ㅇ). Tectonophysics 394, 193-219.

Marsh, R.E., Prestwich, W.V., Rink, W.J., Brennan, B.J., 2002. Monte Carlo determinations of the beta dose rate to tooth enamel. Radiat. Meas. 35, 609-616.

Martinson, D.G., Pisias, N.G., Hays, J.D., Imbrie, J., Moore, T.C., Shackleton, N.J., 1987. Age dating and the orbital theory of the ice ages - development of a high-resolution 0 to 300,000-year chronostratigraphy. Quat. Res. 27, 1-29.

McLaren, S.J., 1993. Use of cement types in the palaeoenvironmental interpretation of coastal aeolianite sequences. In: Pye, K. (Ed.), The Dynamics and Environmental Context of Aeolain Sedimentary Systems. Geological Society Special Publication 72 Geological Society, London, pp. 235-244.

McLaren, S.J., 2007. Aeolianite. In: Nash, D.J., McLaren, S.J. (Eds.), Geochemical Sediments and Landscapes. Blackwell, Oxford, pp. 144-172.

Muhs, D.R., Simmons, K.R., Schumann, R.R., Groves, L.T., DeVogel, S.B., Minor, S.A., Laurel, D., 2014. Coastal tectonics on the eastern margin of the Pacific Rim: late Quaternary sea-level history and uplift rates, Channel Islands National Park, California, USA. Quat. Sci. Rev. 105, 209-238.

Mujica, M.I., Latorre, C., Maldonado, A., González-Silvestre, L., Pinto, R., de Pol-Holz, R., Santoro, C.M., 2015. Late Quaternary climate change, relict populations and presentday refugia in the northern Atacama Desert: a case study from Quebrada La Higuera $\left(18^{\circ} \mathrm{S}\right)$. J. Biogeogr. 42, 76-88.

Muñoz, R.C., Garreaud, R.D., 2005. Dynamics of the low-level jet off the west coast of subtropical South America. Mon. Weather Rev. 133, 3661-3677.

Murray, A.S., Wintle, A.G., 2003. The single aliquot regenerative dose protocol: Potential for improvements in reliability. Radiat. Meas. 37, 377-381.

Murray-Wallace, C.V., Bourman, R.P., Prescott, J.P., Williams, F., Price, D.M., Belperio, A.P., 2010. Aminostratigraphy and thermoluminescence dating of coastal aeolianites and the later Quaternary history of a failed delta: the river Murray mouth region, South Australia. Quat. Geochronol. 5, 28-49.

Nathan, R.P., Mauz, B., 2008. On the dose-rate estimate of carbonate-rich sediments for trapped charge dating. Radiat. Meas. 43, 14-25. 
Paskoff, R., Cuitiño, L., Manríquez, H., 2003. Origen de las arenas dunares de la región de Copiapó, Desierto de Atacama, Chile. Rev. Geol. Chile 30, 355-361.

Pfeiffer, M., Aburto, F., Le Roux, J.P., Kemnitz, H., Sedov, S., Solleiro-Rebolledo, E., Seguel, O., 2012. Development of a Pleistocene calcrete over a sequence of marine terraces at Tongoy (north-central Chile) and its palaeoenvironmental implications. Catena 97, 104-118.

Placzek, C., Quade, J., Betancourt, J.L., Patchett, P.J., Rech, J.A., Latorre, C., Matmon, A., Holmgren, C., English, N.B., 2009. Climate in the dry central Andes over geologic, millennial, and interannual timescales. Ann. Mo. Bot. Gard. 96, 386-397.

Placzek, C.J., Quade, J., Platchett, P.J., 2013. A 130 ka reconstruction of rainfall on the Bolivian Altiplano. Earth Planet. Sci. Lett. 363, 97-108.

Porat, N., Botha, G., 2008. The luminescence chronology of dune development on the Maputaland coastal plain, southeast Africa. Quat. Sci. Rev. 27, 1024-1046.

Prescott, J.R., Hutton, J.T., 1994. Cosmic ray contributions to dose rates for luminescence and ESR dating: large depths and long-term variations. Radiat. Meas. 23, 497-500.

Preusser, F., Radies, D., Matter, A., 2002. A 160,000-year record of dune development and atmospheric circulation in southern Arabia. Science 296, 2018-2020.

Quade, J., Rech, J.A., Betancourt, J.L., Latorre, C., Quade, B., Rylander, K.A., Fisher, T., 2008. Paleowetlands and regional climate change in the central Atacama Desert, northern Chile. Quat. Res. 69, 343-360.

Quezada, J., Gonzalez, G., Dunai, T., Jensen, A., Juez-Larre, J., 2007. Pleistocene littoral uplift of northern Chile: ${ }^{21} \mathrm{Ne}$ age of the upper marine terrace of Caldera-Bahia Inglesa area. Rev. Geol. Chile 34, 81-96.

Roberts, D.L., Bateman, M.D., Murray-Wallace, C.V., Carr, A.S., Holmes, P.J., 2009. West coast dune plumes: climate driven contrasts in dunefield morphogenesis along the western and southern South African coasts. Palaeogeogr. Palaeoclimatol. Palaeoecol. 271, 24-38.

Rodnight, H., 2008. How many equivalent dose values are needed to obtain a reproducible distribution? Ancient TL 26, 3-9.

Rodríguez, M.P., Carretier, S., Charrier, R., Saillard, M., Regard, V., Hérail, G., Hall, S., Farber, D., Audin, L., 2013. Geochronology of pediments and marine terraces of north-central Chile and their implications for Quaternary uplift in the western Andes Geomorphology 180-181, 33-46.

Rundel, P.W., Dillon, M.O., Palma, B., Mooney, H.A., Gulmon, S.L., Ehleringer, J.R., 1991. The phytogeography and ecology of the coastal Atacama and Peruvian deserts. Aliso 13, 1-49.

Rutllant, J., Montecino, V., 2002. Multiscale upwelling forcing cycles and biological response off north-central Chile. Rev. Chil. Hist. Nat. 75, 217-231.

Saavedra, N., Müller, E.P., Foppiano, A.J., 2010. On the climatology of surface wind direction frequencies for the central Chilean coast. Aust. Meteorol. Oceanogr. J. 60, 103-112.

Saillard, M., Hall, S.R., Audin, L., Farber, D.L., Hérail, G., Martinod, J., Regard, V., Finkel, R.C., Bondoux, F., 2009. Non-steady long-term uplift rates and Pleistocene marine terrace development along the Andean margin of Chile $\left(31^{\circ} \mathrm{S}\right)$ inferred from ${ }^{10} \mathrm{Be}$ dating. Earth Planet. Sci. Lett. 277, 50-63.

Saillard, M., Hall, S.R., Audin, L., Farber, D.L., Regard, V., Hérail, G., 2011. Andean coastal uplift and active tectonics in southern Peru: ${ }^{10} \mathrm{Be}$ surface exposure dating of differentially uplifted marine terrace sequences (San Juan de Marcona, $\sim 15.4^{\circ} \mathrm{S}$ ). Geomorphology 128, 178-190.

Saillard, M., Riotte, J., Regard, V., Violette, A., Hérail, G., Audin, L., Riquelme, R., 2012. Beach ridges U-Th dating in Tongoy bay and tectonic implications for a peninsula-bay system, Chile. J. S. Am. Earth Sci. 40, 77-84.

Saye, S.E., Pye, K., Clemmensen, L.B., 2006. Development of a cliff-top dune indicated by particle size and geochemical characteristics: Rubjerg Knude, Denmark. Sedimentology 53, 1-21.

Segerstrom, K., 1962. Deflated marine terrace as a source of dune chains, Atacama Province, Chile. US Geol. Surv. Prof. Pap. 450-C.

Short, A.D., 2014. Australia's temperate carbonate coast: sources, depositional environments and implications. In: Martini, I.P., Wanless, H.R. (Eds.), Sedimentary Coastal Zones from High to Low Latitudes: Similarities and Differences. Geological Society, London, Special Publications 388. pp. 389-405.

Shulmeister, J., Goodwin, I., Renwick, J., Harle, K., Armand, L., McGlone, M.S., Cook, E., Dodson, J., Hesse, P.P., Mayewski, P., Curran, M., 2004. The Southern hemisphere westerlies in the Australasian sector over the last glacial cycle: a synthesis. Quat. Int. 118-119, 23-53.

Stuut, J.-B.W., Lamy, F., 2004. Climate variability at the southern boundaries of the Namib (southwestern Africa) and Atacama (northern Chile) coastal deserts during the last 120,000 years. Quat. Res. 62, 301-309.

Stuut, J.B.W., Crosta, X., Van der Borg, K., Schneider, R.R., 2004. The relationship between Antarctic sea ice and south-western African climate during the late Quaternary. Geology 32, 909-912.

Vacher, H.L., 1997. Introduction: varieties of carbonate islands and historical perspective. In: Vacher, H.L., Quinn, T.M. (Eds.), Geology and Hydrogeology of Carbonate Islands. Developments in Sedimentology, vol. 54. Elsevier, Amsterdam, pp. 1-34.

Veit, H., Preusser, F., Trauerstein, M., 2015. The southern westerlies in Central Chile during the last two glacial cycles as documented by coastal aeolian sand deposits and intercalating palaeosols. Catena 134, 30-40.

Vuille, M., Ammann, C., 1993. Regional snowfall patterns in the high, arid Andes. Clim. Chang. 36, 413-423.

Waelbroeck, C., Labeyrie, L., Michela, E., Duplessy, J.C., McManus, J.F., Lambeck, K., Balbon, E., Labracherie, M., 2002. Sea-level and deep water temperature changes derived from benthic foraminifera isotopic records. Quat. Sci. Rev. 21, 295-305.

Wilson, P., Vincent, P.J., Telfer, M.W., Lord, T.C., 2008. Optically stimulated luminescence (OSL) dating of loessic sediments and cemented scree in northwest England. The Holocene 18, 1101-1112. 